\title{
Tax Administration
} Reform in

the Francophone Countries of

Sub-Saharan Africa 


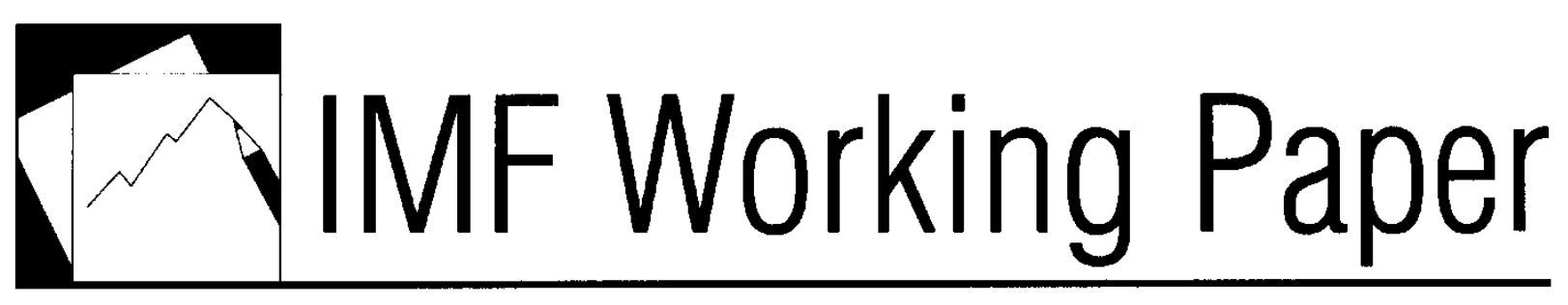

\section{Tax Administration Reform in the Francophone Countries of Sub-Saharan Africa}

Patrick Fossat and Michel Bua 


\title{
IMF Working Paper
}

Fiscal Affairs Department

\section{Tax Administration Reform in the Francophone Countries of Sub-Saharan Africa ${ }^{1}$ by Patrick Fossat and Michel Bua}

Distribution authorized by Katherine Baer

July 2013

\begin{abstract}
Since the early 1990s, major tax administration reforms have been implemented in the Francophone countries of sub-Saharan Africa, with significant support from the IMF and development partners. While the reforms have contributed to an increase in revenues, attention is still needed to address a number of weaknesses in these countries' tax administrations. A review of the conditions for successful modernization of the tax administration shows that significant changes are needed to ensure better utilization of technical assistance, improve the governance of reforms, and provide the tax administrations with greater flexibility in managing their resources.

JEL classification numbers: H20, H25, 055

Keywords: tax administration, reform, modernization, technical assistance

Authors’ e-mail addresses: pfossat@imf.org and mbua@imf.org

This Working Paper should not be reported as representing the views of the IMF. The views expressed in this Working Paper are those of the author(s) and do not necessarily represent those of the IMF or IMF policy. Working Papers describe research in progress by the author(s) and are published to elicit comments to further debate.
\end{abstract}

\footnotetext{
${ }^{1}$ This study has benefited from the comments of experts who were involved in the provision of IMF technical assistance to the tax administrations of the Francophone countries of sub-Saharan Africa during the past 15 years, including Jean-Paul Bodin, Olivier Benon, Gérard Chambas, Anne-Marie Geourjon, Chaouki Hamad, Maureen Kidd, Vincent Koukpaizan, Eric Lesprit, and Stéphane Schlotterberck. The authors and several of these experts wish to stress the key contribution of Jean-Paul Bodin, a former division chief in the IMF's Fiscal Affairs Department, who has been an undisputed leader in the study of issues related to the modernization of the tax administrations in developing countries and countries in transition for a number of years.
} 


\section{Contents}

I. Introduction: Purpose of the Study and Context of Reforms

II. Status of the Tax Administrations in the Early 1990s...............................................11

III. Reforms Implemented Over the Past 15 Years .........................................................14

A. Main Thrust of the Reform Strategies........................................................ 15

B. Modernizing the Tax Administration's Organizational Structure........................ 16

C. Strengthening Voluntary Compliance....................................................... 23

IV. Assessment of Reforms and Main Challenges to be Addressed.................................. $\underline{34}$

A. Domestic Tax Revenues......................................................................... $\frac{34}{35}$

B. Assessment of Reforms ................................................................. $\frac{35}{38}$

C. The Main Challenges .............................................................................

V. Conclusion: The Main Success Factors .............................................................. 42

\section{Tables}

1. International rankings based on business climate, degree of corruption, competitiveness, and human development ................................................................................

2. Technical assistance provided to the tax administrations of the Francophone countries of

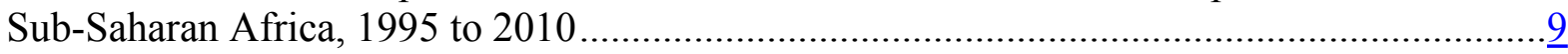

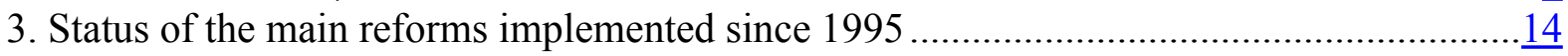

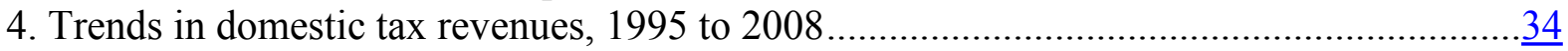

\section{Figures}

1. The main regional treaties in sub-Saharan Africa

\section{Boxes}

1. WAEMU: Recent tax and customs initiatives .7

2. Changes in the tax administration organizational structure ....................................... 17

3. Restructuring the tax office network: the cases of Cameroon and Senegal......................20

4. Changes in tax procedures and methods ................................................................24

5. Advantages of a single threshold and a single rate for VAT ......................................

6. Examples of bad practices in VAT administration .....................................................29

7. Tax administration computerization: Current trends .................................................

8. The main components of a tax audit program ...................................................

\section{Annexes}

1. Assessment of the reforms implemented since 1995 by the tax administrations of the Francophone countries of sub-Saharan Africa. 


\section{Abbreviations and Acronyms}

ADB

AFRITACs

CAR

CDI

CEMAC

CFAF

CFEM

CGE

CIDA

CIME

COMESA

COTS

CREDAF

DFID

DGE

DRC

EAC

ECCAS

ECOWAS

EU

FAD

GDP

HDI

ICF

IMF

IT

LTO

MTO

NIF

OECD

PTF

SADC

SECO

STO

UNDP

USAID

VAT

WAEMU

WB

WEF
African Development Bank

Africa Regional Technical Assistance Centers

Central African Republic

Local tax office (Centre des impôts)

Central African Economic and Monetary Community

CFA franc

Medium-Size Taxpayer Office (Centre fiscal des entreprises moyennes in Senegal)

Large Taxpayer Office (Centre des grandes entreprises in Senegal)

Canadian International Development Agency

Medium-Size Taxpayer Office (Centre des moyennes entreprises in Cameroon)

Common Market for Eastern and Southern Africa

Commercial off-the-shelf

Centre de Rencontres et d'Etudes des Dirigeants des Administrations Fiscales

Department for International Development (of the United Kingdom)

Large Taxpayer Directorate (Direction des grandes entreprises)

Democratic Republic of the Congo

East African Community

Economic Commission of Central African States

Economic Community of West African States

European Union

Fiscal Affairs Department

Gross Domestic Product

Human Development Index

Investment Climate Facility for Africa

International Monetary Fund

Information Technology

Large Taxpayer Office

Medium-Size Taxpayer Office

Taxpayer Identification Number (Numéro d'identification fiscale)

Organization for Economic Co-operation and Development

Fiscal Transition Program

Southern African Development Community

State Secretariat for Economic Affairs (of Switzerland)

Small Taxpayer Office

United Nations Development Program

United States Agency for International Development

Value-added Tax

West African Economic and Monetary Union

World Bank

World Economic Forum 


\section{Introduction: Purpose of The StUdy ANd Context Of Reforms}

This study deals with the reforms undertaken by the tax administrations of 19 Francophone countries of sub-Saharan Africa with the support of the IMF's Fiscal Affairs Department (FAD) since 1995. It comes at a time when the problems associated with the mobilization of domestic tax revenue in developing countries are attracting renewed interest and growing awareness that these resources must be the primary financing source for development, with aid playing essentially a supporting role.

Purpose of the study. More than ever, issues such as modernizing organizational structures and business processes, enhancing capacity building, and strengthening ownership of reforms are central to tax administration reforms. After a decade and a half of significant reforms to improve the functioning of the tax administration, and at a time where progress has slowed in many countries, this study aims to assess the changes that have been introduced, including identifying the difficulties encountered and exploring the appropriate solutions. This review should facilitate the coordination of the development partners' assistance programs to tax reform, including the development of consistent and well-coordinated approaches.

The study is largely based on the findings and conclusions of technical assistance missions carried out by the Fiscal Affairs Department and the IMF's regional technical assistance centers $^{2}$ for 19 Francophone countries in sub-Saharan Africa, including: Benin, Burkina Faso, Burundi, Cameroon, the Central African Republic (CAR), Chad, the Comoros, the Democratic Republic of the Congo (DRC), the Republic of Congo, Côte d'Ivoire, Djibouti, Gabon, Guinea, Madagascar, Mali, Mauritania, Niger, Senegal, and Togo.

These countries cover an area of 10.7 million square kilometers, or more than a third of Africa's landmass. With 250 million inhabitants, they make up a quarter of Africa's population. In 2008 they accounted for 19 percent of the sub-Saharan region's GDP. However, their participation in trade is marginal: Africa's 53 countries accounted for only 3.2 percent of world trade in 2009, of which the Francophone countries of sub-Saharan Africa accounted for less than 1 percent. Thirteen of these countries share a common currency, the CFA franc, which is pegged to the euro. ${ }^{3}$

General characteristics of the 19 countries considered in this paper. The Francophone countries of sub-Saharan Africa can be classified into four categories:

- Countries with petroleum resources: these are mainly the countries in central Africa and on the Gulf of Guinea: Cameroon, Chad, the Republic of Congo, and Gabon.

\footnotetext{
${ }^{2}$ West AFRITAC since 2003, Central AFRITAC since 2007, and South AFRITAC since 2011.

${ }^{3}$ The CFA franc, with an exchange rate of about 656 CFA francs to the euro is used in: Benin, Burkina Faso, Cameroon, CAR, Chad, the Republic of Congo, Côte d'Ivoire, Gabon, Guinea-Bissau, Mali, Niger, Senegal, and Togo.
} 
- Countries with significant natural resources other than petroleum: all the countries reviewed, except Djibouti and the Comoros, have mining operations (particularly gold, diamonds, iron, manganese, uranium, and phosphate), although in only six countries (CAR, Gabon, Guinea, Mali, Mauritania, and Niger) does the mining industry account for more than 10 percent of the countries' tax revenues. ${ }^{4}$

- Countries that have suffered major political crises, including civil wars and coups: since 1995, successful or attempted coups have occurred in eight countries (Chad, CAR, Comoros, Guinea, Madagascar, Mali, Mauritania, and Niger), while four countries have had civil wars (Burundi, the Republic of Congo, DRC, and Côte d'Ivoire).

- Landlocked countries: six countries (Burkina Faso, Burundi, CAR, Chad, Mali, and Niger) have no sea-coast and a seventh (DRC) is largely landlocked. ${ }^{5}$

In the first two categories, revenue collection is strongly influenced by the countries' characteristics, particularly for those with abundant resources from petroleum or mining production, which have sometimes neglected the taxation of other sectors. ${ }^{6}$ For landlocked countries, trade is more difficult and transport costs are higher, which impedes development.

The main regional institutions and the challenge of fiscal transition. ${ }^{7}$ The Francophone countries of sub-Saharan Africa belong to a number of regional institutions (Figure 1), among them the Economic Community of West African States (ECOWAS), the Central African Economic and Monetary Community (CEMAC), and the West African Economic and Monetary Union (WAEMU). ECOWAS has 15 member states, but is not involved in taxation issues. On the other hand, CEMAC and WAEMU have developed regional harmonization programs in the tax and customs areas.

WAEMU has eight member countries: Benin, Burkina Faso, Côte d'Ivoire, Guinea-Bissau, Mali, Niger, Senegal, and Togo. The most important WAEMU initiatives in the tax and customs areas during the period covered by this study are summarized in Box 1.

\footnotetext{
${ }^{4}$ Until 1980, DRC derived more than 60 percent of its revenues from the Congolese mining company, Gécamines. Nowadays, however, the country derives minimal revenues from mining.

${ }^{5}$ DRC, with an area of more than 2.3 million square kilometers, has only a narrow, $43 \mathrm{~km}$ coastal border strip, far away from most of its major cities.

${ }^{6}$ For example, in 2011, the ratio of total revenue to GDP for the Republic of Congo was 46.2 percent, including 37.7 percent for oil revenue. For Gabon the ratio of total revenue was 42.5 percent, including 30.4 percent for oil revenue.

${ }^{7}$ Chambas, La transition fiscale en Afrique : les nouveaux enjeux (2005).
} 
Figure 1. The main regional treaties in sub-Saharan Africa $^{8}$

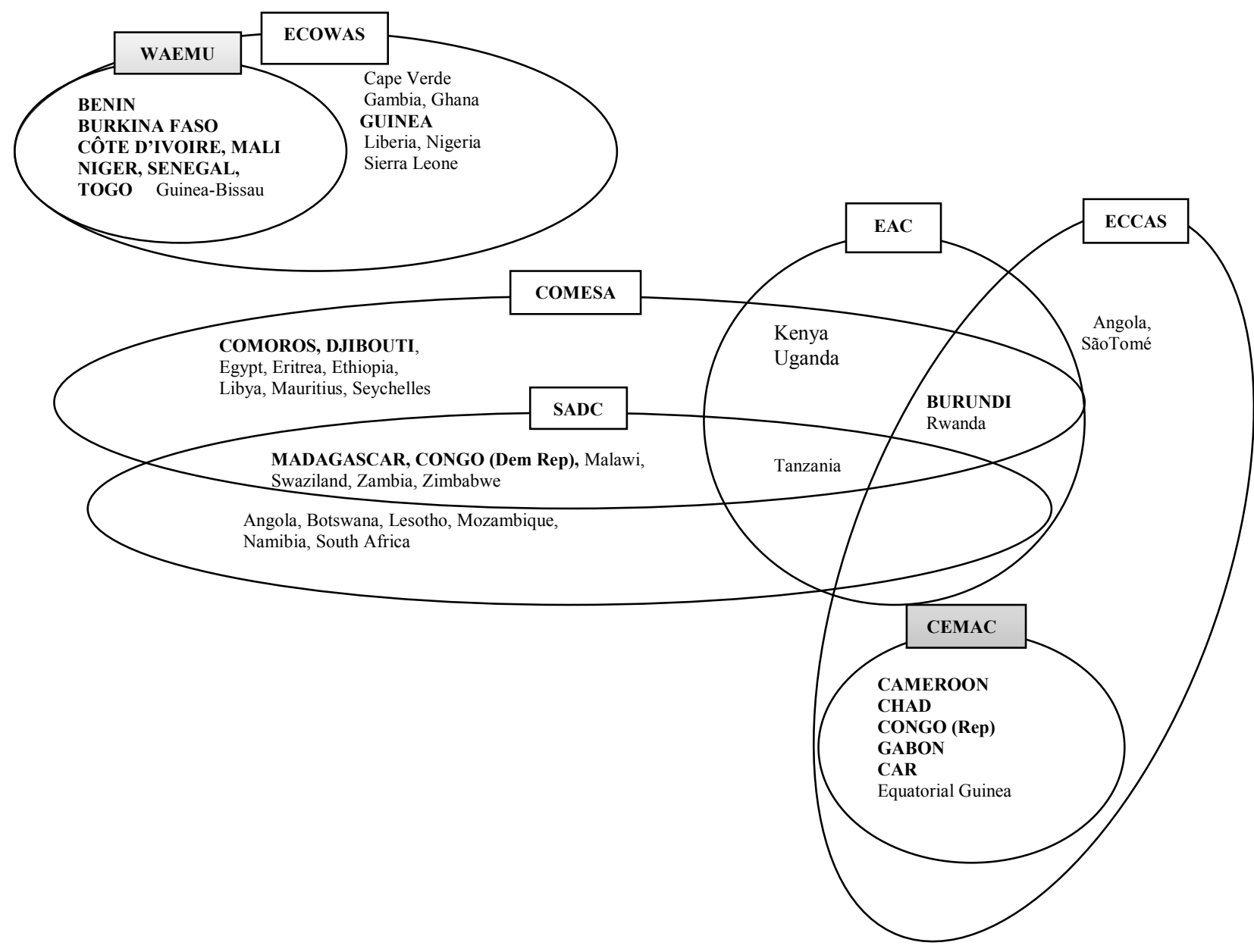

CEMAC has six member countries: Cameroon, CAR, Chad, the Republic of Congo, Equatorial Guinea, and Gabon. Its tax and customs activities have been limited to setting up a common external tariff (1994) and introducing a single personal income tax (2004).

${ }^{8}$ COMESA (Common Market for Eastern and Southern Africa); EAC (East African Community); ECCAS (Economic Community of Central African States); and SADC (Southern African Development Community). 


\section{Box 1. WAEMU: recent tax and customs initiatives}

1998: Defining a harmonized value-added tax (VAT) and excise tax regime to be implemented by December 31, 2001.

1999: Preparing convergence criteria for member countries, four of which were to be achieved by 2002 : (1) keeping the ratio of the wage bill vis-à-vis tax revenues below 35 percent; (2) keeping the ratio of domestically-financed government investments to at least 20 percent of tax revenues; (3) keeping the ratio of the current external deficit excluding grants vis-à-vis nominal GDP below 5 percent; and (4) keeping the tax burden above or equal to 17 percent of GDP. In 2002, no country had achieved the fourth criterion.

2000: Establishing a customs union among the member countries aimed at (1) liberalizing intra-community trade, (2) expanding intra-community trade, and (3) lowering duties on import from outside the community.

2006: Adopting the Fiscal Transition Program (PTF) within the WAEMU to offset declining tax and customs revenues as a result of trade liberalization. The program's main objectives are the following: (1) shifting gradually the tax burden from customs duties to domestic taxes, and (2) fostering economic growth and promoting the financing of development and social policies through the use of internal resources.

The PTF aimed at achieving a tax burden of 17 percent of GDP by 2013, with 10 percent derived from internal revenues and 7 percent from import taxes. To achieve that objective, the member countries were invited to take steps to consolidate the common market, support growth and development financing, strengthen synergies between the tax and customs departments, and strengthen the mobilization of tax and customs revenues. ${ }^{9}$

For instance, Mali set up a national committee in 2010 to define its PTF. Moreover, WAEMU has issued a number of directives and decisions regarding direct tax harmonization. It has also done studies with particular reference to the taxation of small and medium-sized businesses, harmonization of taxes applicable to petroleum products, and harmonization of procedures to monitor tax exemptions.

\section{Rankings for the 19 Francophone countries of sub-Saharan Africa in terms of business} climate, integrity, and development. The performance of a tax administration is influenced by the environment in which it operates. In an effort to assess this environment, international agencies have developed indicators to measure the business climate, the extent of corruption, the competitiveness, and the level of human development (Table 1).

Overall, these rankings show poor performance in the 19 countries in all areas:

- Given the complexity of procedures for starting, taxing, managing, and closing a business, these countries rank among the least efficient in the Doing Business Survey published by the World Bank.

- Endemic corruption, with its negative repercussions on the level of tax revenues and the quality of international trade, is highlighted in the ranking by Transparency International.

\footnotetext{
${ }^{9}$ The program proposes 47 measures that were developed during a seminar on "Taxation and Development," which was organized by the WAEMU Commission in December 2005.
} 
- The countries' weak level of competitiveness, a contributing factor to weak tax revenue performance, is reflected in the World Economic Forum's ranking, which places these countries at the bottom of the ladder.

- The development gap, which can be assessed by purchasing power, level of education, and life expectancy explains why the vast majority of these countries are in the bottom of the Human Development Index prepared by the United Nations Development Program.

To a large extent, this very weak performance can be explained by the difficult conditions prevailing in sub-Saharan Africa, in particular the cumulative adverse effects of repeated political conflicts and social unrests, the chronic levels of political instability, inadequate infrastructure and education systems, and a large, pervasive informal sector.

\section{Table 1. International rankings based on business climate, degree of corruption, competitiveness, and human development}

\begin{tabular}{|l|c|c|c|c|c|c|c|c|}
\hline & \multicolumn{2}{|c|}{$\begin{array}{c}\text { Business Climate } \\
\text { (Doing Business) }\end{array}$} & \multicolumn{3}{|c|}{$\begin{array}{c}\text { Corruption } \\
\text { (Transparency International) }\end{array}$} & $\begin{array}{c}\text { Competitiveness } \\
\text { (World Economic } \\
\text { Forum) }\end{array}$ & $\begin{array}{c}\text { Human Development } \\
\text { Index (UNDP) }\end{array}$ \\
\cline { 2 - 9 } & $\begin{array}{c}2006 \\
(175 \\
\text { countries) }\end{array}$ & $\begin{array}{c}2012 \\
(185 \\
\text { countries) }\end{array}$ & $\begin{array}{c}2004 \\
(146 \\
\text { countries) }\end{array}$ & $\begin{array}{c}2008 \\
(180 \\
\text { countries) }\end{array}$ & $\begin{array}{c}2012 \\
(176 \\
\text { countries) }\end{array}$ & $\begin{array}{c}2012-13 \\
(144 \text { countries) }\end{array}$ & $\begin{array}{c}2007 \\
(182 \\
\text { countries) }\end{array}$ & $\begin{array}{c}2012 \\
(187 \\
\text { countries) }\end{array}$ \\
\hline Benin & 139 & 175 & 77 & 96 & 94 & 119 & 161 & 166 \\
Burkina Faso & 171 & 153 & & 80 & 83 & 133 & 177 & 183 \\
Burundi & 160 & 159 & & 158 & 165 & 144 & 174 & 178 \\
Cameroon & 147 & 161 & 129 & 141 & 144 & 112 & 153 & 150 \\
CAR & 162 & 185 & & 151 & 144 & & 179 & 180 \\
Chad & 172 & 184 & 142 & 173 & 165 & 139 & 175 & 184 \\
Comoros & & 158 & & 134 & 133 & & 139 & 169 \\
Congo (Rep.) & 169 & 183 & 114 & 158 & 144 & & 136 & 142 \\
Côte d'Ivoire & 156 & 177 & 133 & 151 & 130 & 131 & 163 & 168 \\
Djibouti & 152 & 171 & & 102 & 94 & & 155 & 164 \\
DRC & 141 & 181 & 133 & 171 & 160 & & 176 & 186 \\
Gabon & 129 & 170 & 74 & 96 & 102 & 99 & 103 & 106 \\
Guinea & 149 & 178 & & 173 & 154 & 141 & 170 & 178 \\
Madagascar & 148 & 142 & 82 & 85 & 118 & 130 & 145 & 151 \\
Mali & 166 & 151 & 77 & 96 & 105 & 128 & 178 & 182 \\
Mauritania & 146 & 167 & & 115 & 123 & 134 & 154 & 155 \\
Niger & 170 & 176 & 122 & 115 & 113 & & 182 & 186 \\
Senegal & 152 & 166 & 85 & 85 & 94 & 117 & 166 & 154 \\
Togo & 154 & 156 & & 121 & 128 & & 159 & 159 \\
\hline
\end{tabular}

Technical assistance programs in the tax administration area. Since 1995, the IMF's Fiscal Affairs Department and other development partners have provided technical assistance to all the tax administrations of the countries discussed in this paper (Table 2). 


\section{Table 2. Technical assistance provided to the tax administrations of the Francophone countries of Sub-Saharan Africa, 1995 to 2010}

\begin{tabular}{|c|c|c|c|c|c|}
\hline & \multicolumn{4}{|c|}{$\begin{array}{l}\text { Technical assistance received from the IMF } \\
\text { (in person-months) }\end{array}$} & \multirow{2}{*}{ Other development partners $1 /$} \\
\hline & $\begin{array}{l}\text { FAD } \\
\text { missions }\end{array}$ & $\begin{array}{l}\text { FAD short- } \\
\text { term } \\
\text { experts }\end{array}$ & AFRITACs & FAD long-term experts & \\
\hline Benin & 5.5 & 1 & 11.5 & & CIDA, France, Japan \\
\hline Burkina Faso & 2.5 & 4 & 11 & & France, Japan, SECO \\
\hline Burundi & 3 & 6.5 & 12 & & Belgium, DFID, EU, France, Japan, WB \\
\hline Cameron & 4.5 & 5 & 4.5 & 1998-2001 and 2006 (40 months) & France, Japan \\
\hline CAR & 3 & 8.5 & 7 & 2004 (3 months) & EU, France, Japan, WB \\
\hline Chad & 2 & & 5 & 1999-2001(18 months) & EU, France, WB \\
\hline Comoros & 2 & 0.5 & 1 & & France \\
\hline Congo (Rep.) & 1 & & 6.5 & 1995-96 (24 months) & France \\
\hline Côte d'Ivoire & 2.5 & & 6.5 & & France, Japan \\
\hline Djibouti & 2.5 & 2.5 & & & France, Japan \\
\hline $\mathrm{DRC}$ & 4.5 & 3.5 & 4.5 & $\begin{array}{l}\text { 2002-04, 2007-08, 2011-12 } \\
\text { (61 months) }\end{array}$ & $\begin{array}{l}\text { AfDB, Belgium, EU, France, Japan, } \\
\text { MNRW-TTF, TPA-TTF, WB }\end{array}$ \\
\hline Gabon & 2 & 1 & 5 & & France \\
\hline Guinea & 2 & & 2.5 & & France \\
\hline Madagascar & 1.5 & 2 & & 1996-97 and 2006-07 (36 months) & France, Japan \\
\hline Mali & 3 & 3 & 3.5 & 1999-2000 (15 months) & CIDA, France, Japan \\
\hline Mauritania & 3.5 & 4.5 & 4 & 1999-2001 (24 months) & EU, France, Japan, TPA-TTF, WB \\
\hline Niger & 3 & 1 & 5.5 & 2002-03 (24 months) & France, Japan \\
\hline Senegal & 4 & 2 & 5.5 & 2011-2012 (23 months) & $\begin{array}{l}\text { AfDB, EU, France, Japan, TPA-TTF, } \\
\text { WB }\end{array}$ \\
\hline Togo & 2 & & 8 & 1995-96 (24 months) & AfDB, France, Japan, WB \\
\hline
\end{tabular}

1/ AfDB (African Development Bank); AFRITACs (African Regional Technical Assistance Centers); CIDA (Canadian International Development Agency); DFID (Department for International Development, United Kingdom); EU (European Union); SECO (State Secretariat for Economic Affairs, Switzerland); and WB (World Bank). The Tax Policy and Administration Topical Trust fund (TPA-TTF) and Managing Natural Resource Wealth Topical Trust fund (MNRW-TTF) are multi-donor trust fund.

The IMF has provided significant technical assistance to the Francophone countries of subSaharan Africa. Until 2003, this assistance was provided essentially through missions from headquarters and resident experts (often for one or two years). This type of assistance has been adapted after the creation of three African Technical Assistance Centers (AFRITACs): West AFRITAC $^{10}$ in Bamako in June 2003, Central AFRITAC ${ }^{11}$ in Libreville in 2007, and

\footnotetext{
${ }^{10}$ West AFRITAC covers 10 countries: Benin, Burkina Faso, Côte d'Ivoire, Guinea, Guinea-Bissau, Mali, Mauritania, Niger, Senegal, and Togo.

${ }^{11}$ Central AFRITAC covers 8 countries: Burundi, Cameroon, CAR, Chad, DRC, the Republic of Congo,

Equatorial Guinea, and Gabon.
} 
South AFRITAC ${ }^{12}$ in Port Louis in 2011. The AFRITACs' technical assistance programs include short-term missions (one to three weeks) undertaken by the AFRITAC advisors ${ }^{13}$ and/or international experts, and regional workshops.

Until 2005, the tax reforms most frequently supported by IMF technical assistance were the preparations for adoption of VAT, establishment of a large taxpayer office, and implementation of a taxpayer registration system. Since 2005, the assistance provided to the tax administrations has focused on developing and implementing modernization strategies, introducing taxpayer segmentation and risk management, developing performance assessment systems, and improving taxpayer services and audit.

France is still particularly active in the 19 Francophone countries of sub-Saharan Africa, providing them with three types of support: (1) secondment of tax advisors to the tax administrations (all countries other than Togo have had resident advisors); (2) training; and (3) project support (drafting tax codes, purchasing computer equipment, etc.).

External financing of IMF assistance by donors has increased in recent years, particularly through direct bilateral funding and implementation of the AFRITACs. This assistance is aimed at developing reform strategies and monitoring their implementation.

In addition to this introductory chapter reviewing the context of the tax administrations in the Francophone countries of sub-Saharan Africa, this paper comprises four other chapters: status of the tax administrations in the early 1990s (Chapter II); reforms implemented over the past 15 years (Chapter III); assessment of the reforms and main challenges to be addressed (Chapter IV); and a review of the main success factors (Chapter V).

\footnotetext{
${ }^{12}$ South AFRITAC covers 13 countries: Angola, Botswana, Comoros, Lesotho, Madagascar, Mauritius, Mozambique, Namibia, Seychelles, South Africa, Swaziland, Zambia, and Zimbabwe.

${ }^{13}$ Central AFRITAC has an advisor for both tax and customs administration. West AFRITAC and South AFRITAC have two advisors, one for each area.
} 


\section{Status Of The TAX Administrations in The EARLY 1990S}

This chapter describes the situation of the tax administrations of the Francophone countries of sub-Saharan Africa in the early 1990s and outlines their main weaknesses. As indicated subsequently, despite the efforts undertaken for more than a decade and a half, significant improvements are still needed in many countries regarding several issues discussed below.

Tax-based organizational structures. For 10 of the 19 Francophone countries, ${ }^{14}$ tax administration was fragmented into a number of separate organizations or departments responsible for direct taxation, indirect taxation, and stamp duties. This structure had several drawbacks: every taxpayer had to deal with a number of different tax offices using different procedures; there was no coordination between the assessment, audit, and collection functions of the different departments; there were several different, complex identification systems in each organization, as well as different systems of penalties, some of them excessive; and, overall, compliance and administrative costs were high for taxpayers and the tax administration.

\section{Split of the assessment and collection responsibilities between the tax administration and} the Treasury. ${ }^{15}$ This situation was typical in most Francophone countries until recently, including in 16 countries covered by this paper (See Table 3). It had a number of drawbacks, including: a significant additional workload for the tax offices (i.e., the requirement to prepare detailed tax statements or "tax rolls" for the Treasury, which included information regarding the assessment and calculation of the tax owed by each taxpayer and for each tax); a multiplicity of steps for the taxpayer who had to deal with different offices (which resulted in unnecessarily high compliance costs); the use of different, often incompatible, IT systems by the tax office and the Treasury office; a lack of accountability for collection performance (with one office in charge of assessment and audit, the other in charge of collection and enforcement); and significant, consistently increasing delays in collecting the taxes due. ${ }^{16}$ This situation resulted in high costs, complex procedures for both the tax administration and taxpayers, and significant uncollectible tax arrears.

The lack of headquarters (or divisions) units dedicated to policy, planning, and supervision for the key tax administration functions. In most of the 19 countries, the headquarters units in principle responsible for policy and planning were also involved in tax operations (including assessment, audit, and collection for a number of important taxpayers). In the absence of an effective headquarters office structured along functional lines, the capacity to set strategic direction, design taxpayer services and audit programs, and to monitor local

\footnotetext{
${ }^{14}$ Burkina Faso, Cameroon, Comoros, DRC, Republic of Congo, Côte d'Ivoire, Djibouti, Gabon, Madagascar, and Senegal.

${ }^{15}$ Typically the Direction du Trésor et de la comptabilité publique in many Francophone countries.

${ }^{16}$ The entire assessment and collection process frequently lasted several months, and in some extreme cases, several years.
} 
offices' performance were grossly inadequate. Of course, this shortcoming also had a negative impact on the capacity to prepare and implement reforms.

A highly centralized organization. In the tax administrations based on the traditional French model, the lack of proper policy and planning capacity was often aggravated by inadequate delegation of authority (in particular, the power to sign the tax rolls prepared by the tax offices for the Treasury and the power to make decisions on tax disputes, which often rested only with the headquarters managers or, in some cases, only with the head of the tax administration or even the minister of finance). In many countries, the absence of the head of the tax administration could easily paralyze the handling of major tax files.

\section{A tax office network generally based on a geographical division of the country and the multiplication of local offices in an attempt to provide close monitoring of all taxpayers.} This approach, based on the notion of "proximity," was (and in some cases still is) the overriding principle for organizing the tax office network in the countries covered by this study. This approach led to a proliferation of local offices. A new approach focusing on an organizational structure according to the type of taxpayer was gradually introduced in the 1990s (starting in Benin) with establishment of dedicated large taxpayer offices.

Complex tax legislation. In the area of direct taxation, some countries operated either a general income tax, or a schedular income tax, or some combination of the two. Regarding indirect taxation, tax systems were characterized by complex turnover taxes and in some cases by "first generation" VATs with multiple rates levied on a narrow base. The complexity of the legislation and the lack of appropriate documentation (especially a general tax code and a tax procedure code) clearly hindered efforts to promote tax compliance.

Complicated and burdensome procedures. Procedures remained largely based on actions by tax officials to determine the base and assess the amount of tax to be paid. Apart from turnover taxes and VAT, taxes most often were calculated by the tax offices. Taxpayers had to cope with complicated, burdensome formalities to fulfill their tax obligations. ${ }^{17}$ In the absence of a unified registration number or due to a variety of numbers for different purposes, taxpayer identification problems complicated the tax offices' assessment and collection tasks.

Extensive use of manual procedures due to the lack of IT systems. Except for a few tentative efforts to develop tax administration computer systems, usually limited to tax collection and in most countries to the large taxpayer office (e.g., Benin, Cameroon, and Gabon) procedures were essentially manual. As a result, statistics were unreliable, tax data were not secure, and there was no proper follow-up of outstanding taxes.

Lack of resources for taxpayer information and education. Information campaigns were sometimes organized when reforms were introduced, but they were rarely pursued in

\footnotetext{
${ }^{17}$ It was not uncommon for taxpayers to visit several different offices to file their returns and pay their taxes.
} 
subsequent years. Overall, raising public awareness and educating taxpayers were not a major concern for the tax offices, whose efforts focused primarily on enforcement and audit.

Obvious weaknesses in human resource management. Human resource management was largely neglected. No country had developed a staff management plan to ensure that staff's capacities properly matched the tax administration's requirements. Professional training was inadequate in spite of the support provided by the French government (through training provided on site and at the French National Tax School in Clermont-Ferrand).

Furthermore, inadequate salaries and the use of badly designed incentive systems, which had the perverse effect of dealing only with tax auditors and neglecting all other tax officials, undermined staff compliance with basic ethical standards and encouraged corruption. In connection to this, internal audit and the evaluation of staff performance were not seen as a priority, and the amount of revenue collections was the primary (if not the only) criterion for evaluation. In these areas, progress made since the 1990s has been particularly inadequate.

Overall, tax administrations' performance was frequently judged unsatisfactory by IMF technical assistance missions in the early 1990s. For many of the 19 Francophone countries, the missions' main conclusions could be summarized as follows: an inadequate organizational structure with weak policy, planning, and supervision capacities; ineffective and inefficient procedures and taxpayer services; and weak audit and enforcement programs.

Implementation of tax administration reforms was also hampered by an inadequate political support and the insufficient commitment of the tax administration managers, a lack of human and budget resources to support reforms, and a lack of motivation among most tax officers. Political instability and frequent turnover of ministers of finance and tax administration managers made these problems worse in many countries.

One exception was Benin, which received major assistance from the IMF to support its efforts to improve its tax administration in the context of democratic renewal in the early 1990s. Benin's tax reforms during that period-including adoption of a modern VAT, establishment of a large taxpayer office, development of a simplified regime for small taxpayers, and modernization of collection and audit procedures - initially served as models for several other Francophone countries in sub-Saharan Africa.

\footnotetext{
${ }^{18}$ The main features of Benin's VAT, considered as a model in the 1990s by several African countries, included a single rate, a high registration threshold taking into account the tax administration's capacities, a relatively broad base and limited exemptions, and a VAT refund system (Bodin and Koukpaizan, The rise of VAT in Africa: Impact and challenges, 2009).
} 


\section{REFORMS IMPLEMENTEd OVER THE PAST 15 YeARS}

Most of the 19 Francophone countries covered by this study have serious handicaps due to their political and social instability, weak administrative capacity, insufficient economic growth, and a persistent high degree of poverty. Despite these unfavorable circumstances, significant changes, which sometimes led to encouraging progress, were made in some of these countries' tax administrations since 1995. Table 3 summarizes some of the major reforms there were carried out in these countries since 1995.

Table 3. Status of the main reforms implemented since 1995

\begin{tabular}{|c|c|c|c|c|c|c|}
\hline & \multicolumn{2}{|c|}{ Responsibility for tax collection } & \multicolumn{2}{|c|}{ Date of establishment } & \multicolumn{2}{|c|}{ Date of introduction } \\
\hline & Before 1995 & After 1995 & LTO 1/ & MTO 2/ & VAT & TIN 3/ \\
\hline Benin & Tax department (1990) & Tax department & 1990 & 1996 & 1991 & 1991 \\
\hline Burkina Faso & Tax department and Treasury & Tax department (2004) & 2004 & 2004 & 1993 & 1996 \\
\hline Burundi & Treasury & Tax department & 2003 & - & 2009 & 2005 \\
\hline Cameroun & Tax department and Treasury & Tax department (2001) & 2004 & 2006 & 1999 & 1996 \\
\hline CAR & Tax department and Treasury & Tax department (1998) & 1998 & 1998 & 2001 & 2001 \\
\hline Chad & Treasury & Tax department (1999) & 1997 & No & 2000 & 1996 \\
\hline Comoros & Tax department and Treasury & Tax department (2002) & 1994 & - & - & 1994 \\
\hline Congo (Rep.) & Tax department and Treasury & Tax and Treasury 5/ & 1997 & (plan) & 1997 & 2004 \\
\hline Côte d'Ivoire & Treasury & Tax department & 1997 & (plan) & $19604 /$ & 1999 \\
\hline Djibouti & Treasury & Tax department (2001) & 2001 & 2001 & 2009 & 2001 \\
\hline DRC & Tax department & Tax department & 2003 & 2005 & 2012 & 2003 \\
\hline Gabon & Treasury & Tax department (2009) & 2007 & (plan) & 1995 & 1995 \\
\hline Guinea & Treasury & Tax department & 1995 & 2001 & 1996 & 1997 \\
\hline Madagascar & Tax department & Tax department & 1997 & 2002 & 1995 & 1997 \\
\hline Mali & Tax department and Treasury & Tax department(1996) & 1994 & (plan) & 1995 & 1998 \\
\hline Mauritania & Tax department and Treasury & Tax department (2007) & 2000 & 2007 & 1995 & 2001 \\
\hline Niger & Treasury & Tax department (2001) & 1998 & 2003 & $19864 /$ & 1998 \\
\hline Senegal & Tax department and Treasury & Tax department (2010) & 2001 & 2012 & $19804 /$ & 2001 \\
\hline Togo & Treasury & Tax department (1995) & 1995 & 2006 & 1995 & 1995 \\
\hline
\end{tabular}

1/ LTO: large taxpayer office.

2/ MTO: medium-size taxpayer office.

3/ NIF: taxpayer identification number.

4/ Old VAT systems that have been modernized since 1995.

5/ The Treasury department collects additional direct tax assessments and property taxes. 
As in most other developing countries, VAT implementation has generally been a platform to implement tax administration reforms ${ }^{19}$ in the Francophone countries of sub-Saharan Africa. Of the 19 countries, 18 have introduced a VAT and only Comoros has not yet made plans.

In addition, as shown in Table 3: (1) responsibility for tax collection has now been transferred from the Treasury to the tax administration in 18 of the 19 Francophone countries; (2) a large taxpayer office has been established in all of these countries; (3) "segmentation" (see below) has been further developed with the creation of dedicated medium-size taxpayer offices in 12 countries; and (4) all of these countries have established a single taxpayer identification number, which in many cases is also used by the customs and Treasury administrations.

\section{A. Main Thrust of the Reform Strategies}

The reform strategies developed with IMF technical assistance to strengthen the capacity of the tax administration and enhance revenue mobilization have generally focused on the following objectives:

- Fostering tax compliance.

- Reducing taxpayers' compliance costs.

- Improving taxpayer services and ensuring consistency and fairness.

- Reducing the tax administration's costs.

- Increasing transparency and strengthening integrity.

- Developing risk management and combating tax fraud.

- Strengthening collection enforcement and management of tax arrears.

The recommendations provided during the preparation and implementation of these strategies often stressed the conditions that are essential to successful tax administration reform, with emphasis on the following:

- Consistent political support.

- A clear vision of the goals to be met.

- A well-articulated strategy with detailed action plans.

- Streamlined legislation and procedures.

- Motivated and competent management.

- Involvement of all stakeholders, starting with ownership of the reforms by the tax staff.

- Effective internal and external communication.

${ }^{19}$ Ebrill, Keen, Bodin, and Summers, The Modern VAT (IMF, 2001). 
Typically, the reform strategies developed with IMF support in the countries considered in this study have been based on three main pillars:

(1) Merging the tax administration's basic functions into a unified tax administration organized on a functional basis.

(2) Introducing risk management through adoption of segmentation ${ }^{20}$ in developing taxpayer services and audit programs.

(3) Improving tax administration through adoption of a taxpayer identification number, replacement of obsolete administrative assessment procedures with self-assessment procedures, developing taxpayer education programs, and strengthening tax audit.

\section{B. Modernizing the Tax Administration's Organizational Structure}

All 19 countries now have a unified tax administration, which is a major step in the direction of modernizing the administration of tax revenues in the region. This is consistent with developments in many other countries (See Box 2).

Main recommendations to modernize the tax administration organization. Three key recommendations were provided in most of the 19 Francophone countries to modernize the organizational structure and improve the effectiveness of the tax administration:

- Merging all domestic tax operations and key tax administration functions into a unified tax department organized along functional lines.

- Concentrating headquarters activities on management (including policy and program design, planning, and monitoring) and ensuring that tax operations (assessment, audit, and tax collection) are handled by the local offices with appropriate delegation of authority.

- Adopting segmentation to improve the organization and operations of the local tax offices, beginning with establishment of a large taxpayer office.

\footnotetext{
${ }^{20}$ Segmentation is an application of a basic marketing concept (market segmentation) for devising business strategies that take into account the specific characteristics of different customer groups. The application of segmentation to the tax administration has been a key element in the modernization strategies developed since the second half of the 1990s in many countries, including in African countries.
} 


\section{Box 2. Changes in the tax administration organizational structure}

Organization by type of tax. In this traditional model, the tax administrations were specialized by type of tax. In the Francophone countries, three separate departments were typically in charge of direct taxes, indirect taxes, and stamps duties. This structure had several drawbacks, including the lack of comprehensive knowledge of each taxpayer's situation, a multiplicity of offices with which each taxpayer had to deal with, an overlapping of audits, a number of redundant procedures, a lack of cooperation among tax services, increased risks of collusion with taxpayers, and high compliance and administrative costs for the taxpayers and tax offices.

Organization by function. In the 19 countries, as in the vast majority of other African countries, ${ }^{21}$ all domestic taxes are now administered by a unified tax administration. In this prevailing model, the tax administration is organized around units (often called directorates or divisions) based on the main functions-including taxpayer registration and services, audit, collection, resource management, and IT. In this model, all tax information concerning a given taxpayer is gathered within a single file. This structure offers clear advantages vis-à-vis the fragmented structure of the former separate tax departments, including: reduced costs for the tax administration and taxpayers; simplified paperwork and improved services because a taxpayer has to deal with only a single tax office; more effective audit and collection programs; and a unified, consistent treatment of tax obligations.

Introduction of taxpayer segmentation within the local tax offices' structure. Introduction of risk management started with adoption of segmentation in the early 1990s. In developing countries, segmentation is typically based on three main groups of taxpayers: large enterprises, medium-sized enterprises, and small taxpayers. ${ }^{22}$ In a vast majority of cases, development of education and audit programs taking into account the specific needs of these groups and the risks they present began with establishment of large taxpayer offices. In several countries, the concept was then further developed by establishing medium-size taxpayer offices and small taxpayer offices. In this approach, the headquarters and the operational offices (i.e., large, medium, and small taxpayer offices) are still being organized on a functional basis. ${ }^{23}$ In promoting a better use of the available resources based on the risks to be addressed and the needs of the taxpayer categories, adoption of segmentation to reorganize the tax office network should help improve the effectiveness and efficiency of the tax administration.

Strengthening headquarters. In most IMF technical assistance missions' recommendations, strengthening the tax administration headquarters is now seen as a priority to improve policy and program design, planning, and supervision of (1) reform strategies, and (2) the programs to be carried out by the local tax offices to assess, audit, and collect domestic taxes.

\footnotetext{
${ }^{21}$ With development partner support, the administration of domestic taxes has been brought under a single tax authority in the Anglophone countries (Kenya, Ghana, Uganda, Rwanda, Tanzania, Zambia, etc.) since 2000.

${ }^{22}$ It is common in Africa to distinguish small taxpayers (i.e., those with a turnover below the VAT threshold), medium-sized taxpayers, and large taxpayers. The key characteristic of small taxpayers is that they represent the vast majority of taxpayers (80 to 90 percent) while their businesses generate only a small proportion of tax revenues ( 5 to 10 percent or less). On the other hand, it is common for less than 1 percent of large enterprises to generate over 70 percent of tax revenues. Between these two groups, medium-sized enterprises typically represent 10 to 20 percent of all taxpayers and generate 20 to 30 percent of tax revenues (Bodin and Koukpaizan, Taxation of Small Enterprises: Recent Developments, 2008).

${ }^{23}$ In some OECD countries, segmentation has been extended to the headquarters office organization, but it is premature to assess the merits of this change. In any case, it is clear that only those tax administrations that are fully capable of administrating all of the key tax functions can envisage such a radical approach.
} 
While success achieved up to now in this area has been limited, the measures recommended for strengthening the tax administration headquarters are generally as follows:

- A small number of headquarters divisions (or units) structured along functional lines (ideally, no more than five or six units) should be established to handle policy and program design, planning, and monitoring for each of the key functions, including support services (budget, management of resources, and IT) and tax operations (registration, taxpayer services, audit, collection, legislation, and appeals).

- In addition to these divisions, a few smaller, specialized units should be set up for specific functions such as internal audit, communications, and change management.

- Management capacity should be strengthened including, where necessary, selective recruitment of experienced, high-skill professionals and hiring of young staff members with potential for development. To strengthen this capacity, the technical assistance missions have also recommended appropriate delegation of powers to the heads of the operational offices so that headquarters' divisions can focus on their key responsibilities (policy and program design, planning, as well as monitoring).

- The preparation of directives, instructions, and circulars should be significantly improved to ensure the tax laws are more consistently and effectively applied by the operational offices. To achieve this objective, appropriate manuals should also be prepared and more effective staff training programs should be developed, along with internal audit, to improve tax operations in the local tax offices.

- The monitoring of performance and supervision of the local tax offices should be strengthened. In most countries, this requires significant improvements in the production and processing of management information and statistical data. It also calls for developing appropriate tools, including the development of strategic objectives, with benchmarks and performance indicators, and introduction of risk management.

- The governance of reforms should be improved by the creation of appropriate structure responsible for designing strategies and action plans, and monitoring their implementation (e.g., in some countries, a "change management office," see below).

\section{In most Francophone countries of sub-Saharan Africa, headquarters are now organized}

along functional lines. Although progress is still needed to ensure that each of the key functions is properly understood and well developed, the headquarters office often consist of six divisions: (1) human resources and administration; (2) information technology; (3) legislation and appeals; (4) taxpayer registration and services; (5) audit; and (6) collection enforcement. ${ }^{24}$ Apart from these divisions, specialized units, often reporting to the head of

\footnotetext{
${ }^{24}$ In line with the tradition of Francophone countries, some non-core revenue functions such as the management of the land registry (Cadastre) and government properties (Domaines) are still assigned to the tax administration in some countries (e.g., CAR, Congo, Cote d'Ivoire, Niger, Senegal, and Togo). However, the predominant trend is to gradually focus the tax administration responsibilities on its core revenue functions,
} 
the tax administration, have been established in several countries to deal with internal audit, communications, and change management (e.g., in Cameroon, Côte d'Ivoire, Gabon, DRC, Mauritania, Senegal).

Unfortunately, the recommendations to strengthen policy and planning capacities have not always been consistently applied. In many countries, weak management capacities for policy design and supervision (with headquarters staff levels often below the typically recommended share of 5 percent to 10 percent of total staff) contributes to the insufficient revenue performance and the difficulties faced in implementing tax administration reforms over the past 15 years. Moreover, a key factor rarely discussed until now in Francophone countries also relates to the need for significant improvement of the tax administration governance framework, which will be discussed in the next chapter.

Introduction of segmentation and restructuring of the operational offices. Following the merger of the departments that were responsible for different types of taxes and the transfer of the tax collection function to the tax administration, adoption of segmentation has been the most important reform regarding the structure of the tax office network in the past 15 years.

The concept of segmentation led to a review of the traditional organization of the local offices that was based on geographic principles, with a fragmented network of offices aimed at ensuring the provision of services to taxpayers. This approach was relatively common in a number of countries (including France and some OECD countries) before the development of modern communication systems.

In the present circumstances of many of the countries examined in this paper, these commonsense principles are still seen as well suited to the needs of small taxpayers, particularly in remote areas and for the administration of local taxes in most Francophone countries. Nevertheless, adoption of segmentation has resulted in more modern approaches by a move to an organizational structure based on the following principles:

- Creation of specialized structures for administering the large enterprises (in principle, a single, central large taxpayer office).

- Establishment of a limited number of offices for medium-sized enterprises, taking into account the geographic distribution of those businesses (in principle, one or more offices in the capital city and other major cities). ${ }^{25}$

while maintaining the necessary coordination with the specialized agencies dealing with the land registry and the management of government properties.

${ }^{25}$ Although countries may approach this issue in different ways, it is usually recommended that medium taxpayer units be set up in only those areas where there are significant numbers of medium-sized enterprises (at least several hundred). 
- Maintenance of local offices that are essentially devoted to basic services for small taxpayers (registration and information, filing of returns and payment) in the larger cities where a medium taxpayer office has been set up as well as in remote areas.

Box 3 provides an example of these principles as implemented in Cameroon and Senegal.

\section{Box 3. Restructuring the tax office network: The cases of Cameroon and Senegal}

The strategies developed by the tax administrations of Cameroon and Senegal to modernize their network of operational offices is based on three main components:

- A large taxpayer directorate (DGE), with nationwide responsibility for the large enterprises.

- A small number of medium-size taxpayer offices (MTOs) for those enterprises with turnover above the VAT threshold, but below the threshold for administration by the DGE, in the most important cities where there is a sufficient number of medium-sized enterprises.

- Specialized offices for small businesses (with turnover below the VAT threshold), as well as other taxpayers not covered by the DGE or the MTOs.

In Cameroon, the total number of taxable enterprises consists currently of about 500 large enterprises; 15,000 medium-sized enterprises (mostly in Douala and Yaoundé); and 120,000 small businesses. The reorganization of the tax office network to administer these taxpayers was implemented in three stages:

- 2004: creation of a central DGE in Yaoundé with responsibility for administering the large enterprises with annual turnover above CFAF 1 billion.

- 2006: establishment of two MTOs (Centres des impôts des entreprises moyennes, CIME), one in Yaoundé and the other in Douala, to administer the medium-sized enterprises with annual turnover between CFAF 100 million and CFAF 1 billion.

- 2009: launch of the reorganization of other tax offices by setting up pilot tax centers (Centres des impôts $C D I$ ) for small taxpayers in Yaoundé and Douala. Eventually, the existing 100 local tax offices should be replaced by 15 to 20 CDIs.

In Senegal, the number of taxable enterprises is comprised of 500 large enterprises; 10,000 medium-sized enterprises registered for VAT (including about 9,000 located in Dakar), and 40,000 small businesses. The restructuring of the tax office network began in 2001 by setting up a large taxpayer center (Centre des grandes entreprises, $C G E$ ). The plan recently developed to modernize the structure of the operational offices, including the CGE, provides for three main stages:

- 2012: establishment of a pilot MTO (Centres de fiscalité des entreprises moyennes, CFEM) in Dakar.

- 2013: Reform of the CGE that will be transformed in a full-fledge DGE.

- 2012 to 2014: Reorganization of the 20 existing tax offices, which will be replaced by five operational, interregional offices with a network of service units for the small taxpayers in remote areas.

Creation of large taxpayer offices. Each of the tax administrations of the countries being examined now has a dedicated large taxpayer office (see Table 3 above). This measure was generally seen as a priority for securing domestic tax collections and facilitating implementation of significant tax reforms (e.g., adoption or modernization of a VAT) within the framework of structural reform programs supported by the IMF. 
Large taxpayer offices are referred to by different names (directorate, center, or unit) but, whatever the name, the number of enterprises administered is similar in most countries (500 to 1,000 , generating 60 percent to 80 percent of domestic tax revenues). The main criterion for identifying a large enterprise is turnover, but secondary criteria also apply, such as enterprises forming part of a corporate group and industry (e.g., oil, mining, banks, new technologies, and insurance).

In all countries, creation of these offices has been seen as positive. ${ }^{26}$ By assigning a limited number of staff (often fewer than a hundred, typically selected from among the most highly motivated staff), large taxpayer offices have often been able to secure a significant share of tax collections quickly. In many countries, they have also been used as a pilot for the development of new procedures and systems.

Creation of medium-size taxpayer offices. To improve the allocation of available resources and develop better taxpayer services and audit programs for the different categories of taxpayers, several countries have designed the next phase of the reorganization of the tax office network with focus on the administration of medium-sized enterprises. ${ }^{27}$ The segment of medium-sized businesses typically includes the enterprises with turnover above the VAT registration threshold (leaving aside those enterprises administered by the large taxpayer office). In a number of countries (e.g., Benin, Cameroon, CAR, and Senegal), some taxpayers have also been included in this segment based on the nature of their business, regardless of turnover (for instance, professionals, importers, and wholesalers).

Following the creation of large taxpayer offices, implementation of specialized offices for the medium-sized taxpayers is aimed at improving the effectiveness of VAT operations and management of the normal income tax regime, taking into account the specific risks associated with these categories (in particular, failure to file returns and pay the tax due, and underreporting of turnover and taxable incomes). Establishing a limited number of dedicated offices for the medium-sized businesses should also help understand their service and education needs, and develop well-targeted service programs accordingly.

Creation of offices for administering small businesses and micro-enterprises. In several countries, establishing specialized offices for small businesses (generally defined as those with turnover below the VAT threshold) was the logical next step after implementing large and medium-size taxpayer offices.

In most Francophone countries, this step was also linked with a reform of the tax regimes for small businesses and micro-enterprises, which are the vast majority of entrepreneurs (often

\footnotetext{
${ }^{26}$ This positive assessment is consistent with the conclusions of the study conducted in 2002 using a representative sample of countries (Improving Large Taxpayers' Compliance, Katherine Baer, 2002).

${ }^{27}$ This has particularly been the case in Benin (since 1996) and in Burkina Faso, Cameroon, the DRC, Guinea, Madagascar, Mauritania, and Niger (since 2000, Table 3). This approach is also currently being developed in Mali and Senegal (Box 3).
} 
80 percent to 90 percent). ${ }^{28}$ Given the high administrative and compliance costs for both the tax administration and these taxpayers, and the limited amounts of collections from this segment (typically less than 5 percent of domestic tax collections), improving the efficiency and effectiveness of the taxation of small businesses and micro-enterprises is increasingly seen as a key component of many tax administration modernization strategies.

Simplifying the tax obligations of businesses whose incomes are often below the poverty line is also essential for expanding the tax base and helping small business owners and microentrepreneurs to "formalize" their activities in order to facilitate their development. In principle, the tax offices in charge of small businesses and micro-enterprises should focus on educating those taxpayers, with a permanent goal of simplifying their tax obligations and facilitating their integration and retention in the formal economy.

The control of these small taxpayers should fundamentally rely on cross-checking and intelligence operations targeted to those sectors where evasion is frequent (e.g., construction and subcontracting), with a view to broaden the tax base by identifying taxpayers that underreport their turnover to take advantage of a simplified tax regime and avoid their obligations under the VAT and income tax regimes. ${ }^{29}$

Alternative approaches to the proliferation of local tax offices. The need to take into account all taxpayers' needs for services, including small taxpayers in remote areas (for instance, need to register and obtain basic information on tax obligations, filing returns and paying taxes and stamp duties), while hoping also in some cases to detect hidden sources of tax revenue, has led several countries to establish a large number of local tax offices. Given the limited available resources, this approach inevitably leads to difficulties in the management of the tax administration's resources, especially in a frequently tight budget context. That said, a drastic reduction of the number of tax offices in order to optimize the efficient management of those resources raises the basic question of the tax administration's ability to manage the small taxpayers. This is particularly the case with respect to the collection of local taxes which in the Francophone countries are traditionally collected by the central government tax administration.

\footnotetext{
${ }^{28}$ This reform resulted in the repeal of the "forfait" system that had been retained in Francophone countries after independence but no longer served its initial objectives (in terms of simplification for small taxpayers and reduction of tax administration costs). The new regimes are often based on a presumptive tax calculated from a schedule taking turnover into account (e.g., since 2000 in Burkina Faso, Cameroon, Côte d'Ivoire, Mali, Mauritania, Niger, Senegal, and Togo). In Francophone Africa, the other types of simplified regime are the Single Business Tax (Taxe Professionnelle unique) based on the commercial rental value (Benin since 1994) and a more sophisticated regime - and probably one that offers better potential in terms of expanding the tax base - based on a simple cash flow income tax (Madagascar since 2008; see Bodin and Koukpaizan, 2008).

${ }^{29}$ The study of the informal economy in Africa shows a distinction between small and micro operators (including micro traders working in the street and peddlers) and organized fraud (e.g., smuggling and sale in the local market of products intended for export). While the border line may sometimes be fuzzy, the term "informal operator" should be used mainly for the first category.
} 
Over the past 20 years, this dilemma has been resolved in many countries, notably among the members of the OECD and a number of emerging economies, through an increased use of electronic procedures and the provision of tax forms, publications, and basic information over the Internet. In those countries, reducing the number of local offices to increase the efficiency of the tax administration and to improve tax operations has gone hand in hand with improving the information and services provided to taxpayers-including electronic registration, filing, and payment, provision of on-line information on taxpayer rights and obligations, as well as the availability of efficient call centers.

In Francophone Africa as elsewhere, the use of electronic registration, filing, and payment procedures, as well as on-line provision of taxpayer information is now envisaged in most tax administration reform strategies beginning with the large and medium-sized enterprises.

Regarding small taxpayers, particularly in remote areas with a low population density, development of on-line procedures is likely to take much longer. ${ }^{30}$ Despite the constraints, alternative approaches are still possible to improve the provision of basic services to small taxpayers in the areas of taxpayer information, payment of tax and stamp duties, provision of tax forms and publications, while avoiding a proliferation of tax offices.

For instance, it is possible to install small service units ("Guichet fiscal") reporting to the nearest tax office in banks or post offices to provide basic taxpayer services. Similar units can also be set up in municipal cashiers' offices, which could not only accept payments of local taxes and stamp duties, but also provide simple tax brochures. Experience shows that the potential for an effective coordination of the tax offices with local communitiesincluding using the staff of those communities to identify taxable persons and properties and to collect local taxes - is generally insufficiently developed in Francophone Africa.

\section{Strengthening Voluntary Compliance}

The ultimate goal of the changes in the structure of the tax administration-including those related to integration of all key functions and taxes in a unified, function-based tax administration and the introduction of segmentation to improve the structure of the tax offices network - is to implement an appropriate organizational framework to support the functioning of a modern tax system based on voluntary compliance. The main changes in the taxation procedures and methods, including the relatively recent transition in the Francophone countries of sub-Saharan Africa from an "administrative assessment" system ("système déclaratif") to a self-assessment system are presented in Box 4.

\footnotetext{
${ }^{30}$ Although unexpected progress is sometimes possible, as shown by the impact on economic activity of the spread of mobile cellular telephone services in a number of African countries.
} 


\section{Box 4. Changes in tax procedures and methods}

The traditional approach. Tax administration procedures and methods have evolved over the years. In the oldest phase, tax offices had to deal with all the preliminary work leading to the payment of tax, including identifying and assessing the tax base, calculating the tax due, and preparing and sending tax notices to taxpayers. In the Francophone countries, one particular feature of the process (which increased the administrative costs) was the split of responsibilities between two separate departments according to the principle of separation of the assessment and accounting functions ("separation des ordonnateurs et des comptables") that underpinned the organizational structure of these countries' tax administrations until recently.

Based on this principle (which still applies to the local taxes in Francophone countries, especially property taxes) the tax directorate (Direction des impôts) was responsible for assessment and audit, while taxes were paid to the public accounting directorate (Direction du Trésor et de la Comptabilité Publique) that was also responsible for collection enforcement. These arrangements resulted in complex, burdensome procedures, with significant risk of confusion for taxpayers: (1) tax rolls were prepared by the local tax offices, which assembled in a single document the information needed for calculating the amount of tax due by each taxpayer; (2) the rolls were transmitted to the tax administration headquarters for approval and certification by the general tax director or, in some of the countries covered by this study (including Senegal), by the minister of finance; (3) the rolls were then transmitted by the minister to the headquarters of the public accounting directorate; and finally (4) tax notices were prepared and sent to each taxpayer by the local offices of this directorate.

Transition to an administrative-assessment system. In the second half of the last century, adoption of income tax systems led to the implementation of another approach in which the tax base was calculated and reported to the tax administration by the taxpayer. This approach, basically known as the "système déclaratif" in Francophone countries, was an "administrative assessment" system with emphasis on the assessment of the tax base declared by the taxpayer and, as needed, post audit, including the use of specialized audit offices (such as the central audit directorate that were created in most Francophone countries). This procedure generally resulted in an acceleration of the payment process, with quarterly installments and payment (or refund) of the tax due following a review of each tax return and issuance of a tax notice by the tax office.

In Francophone countries, the potential advantages of this change have unfortunately been undermined by the split of the assessment and collection functions between two separate directorates. Maintenance of this dual organization until quite recently significantly weakened the audit function because of the fragmentation of responsibilities and unnecessarily complicated business processes, which resulted in lack of effectiveness of the public accounting directorate in collecting additional taxes due following an audit.

Introduction of self assessment. Most recently (in the past 20 years in Francophone Africa), adoption of VAT has been accompanied by the introduction of self-assessment procedures that now characterizes modern tax systems based on voluntary compliance. In these procedures, the amount of tax is calculated and paid by taxpayers when filing their tax returns. In these procedures, emphasis is placed on the development of taxpayer identification systems and balanced compliance programs taking into account (1) the taxpayers' needs for education and simplification of their filing and payment obligations, and (2) the need for effective collection enforcement and well-targeted audit procedures.

Consolidating segmentation and developing risk management in a fully computerized environment are essential preconditions to ensure the effectiveness and efficiency of such programs in a self assessment system.

The approach developed to promote voluntary compliance is based on a proper balance between two principles:

- Helping taxpayers and their representatives understand their tax obligations and facilitating compliance with these obligations. 
- Implementing programs to promote tax compliance, including prompt identification and sanction of delinquent taxpayers (both "stopfilers" and "nonpayers"), and tax audit.

The IMF missions' recommendations to implement this approach have focused on the necessary conditions for the effective functioning of a self-assessment system, including:

- Simplifying tax legislation.

- Developing taxpayer education and information programs to facilitate understanding of, and compliance with, tax obligations.

- Simplifying registration, filing, payment, and refund procedures and forms.

- Ensuring prompt identification and actions against delinquent taxpayers.

- Improving the quality of audit, including improvements in the selection of files to be audited and in audit methods.

- Improving penalties to foster more effective tax compliance (strengthening deterrence) and making them more equitable (ensuring that penalties are proportionate to the severity of the underreporting or fraud identified).

- Strengthening taxpayers' rights and establishing an independent appeal mechanism.

Several of the IMF recommendations implemented in the Francophone countries of subSaharan Africa are examined below.

Simplifying tax legislation. In most countries, the preparations for adoption of VAT or reform of an old VAT system and regional harmonization of the indirect tax system provided an opportunity to simplify legislation. As discussed in Box 5, simple legislation (including a single VAT rate and a single, sufficiently high registration threshold) is certainly easier to understand and to apply from the standpoint of both taxpayers and the tax administration.

Despite the advantages of a single rate, policy makers are often under pressure to favor the consumption of certain products or services. ${ }^{31}$ Thus, following the commodity price increases in 2008, some WAEMU member countries proposed an amendment of the Union directives aimed at allowing countries to adopt a reduced VAT rate for widely consumed staples. ${ }^{32}$

\footnotetext{
${ }^{31}$ The sectors vary depending on circumstances: basic food stuffs, restaurants, music and film industry, smallengine cars, construction of social housing, tourism, etc.

${ }^{32}$ To some extent, this seems influenced by the high VAT rates adopted in Francophone African countries (often in a 18 percent to 20 percent range, compared with 12 percent to 15 percent elsewhere in Africa).
} 
However valid those countries' concerns may have been, the proposal clearly posed a serious risk of undermining the VAT - its consequences in terms of additional complexity for the tax administration need to be carefully assessed. Experience shows that the redistributive effect of a reduced VAT rate is unclear. A number of recent studies have shown that reduced VAT rates, including zero-rates for domestic sales provide benefits to well-off families whose consumption of the products and services subject to a reduced rate is much greater than that of the poor. ${ }^{33}$

\section{Box 5. Advantages of a single threshold and a single rate for VAT}

A single VAT threshold. A single registration threshold that is applied to all taxpayers, whether natural or legal persons, has clear advantages:

- It is often difficult to classify small operators engaging in a variety of activities involving the sale of goods and provision of services in order to determine the applicable threshold. Adopting a single threshold eliminates the need for such a classification.

- Applying the threshold to small businesses incorporated as legal entities helps simplify their tax obligations and reduce their compliance costs. It also increases the tax administration's efficiency and effectiveness by focusing the available resources on administering VAT for the enterprises above the threshold.

A single rate. The vast majority of the countries where a VAT has been introduced since the early 1990s have adopted a single VAT rate. The main reasons for this decision are the following:

- Adoption of a single rate facilitates record keeping and invoicing. There is no need to ensure a different classification of the purchases and sales of goods and services, contrary to the situation in countries with a multiple-rate VAT.

- It also helps simplify the VAT return form, which can be limited to a single page to facilitate its preparation by the enterprise and its processing by the tax administration.

- A single rate also facilitates desk verifications (e.g., reconciliation of information provided in the income tax and VAT returns) and VAT audits (auditors can focus on checking the accuracy of reported sales and expenses instead of the distribution of sales and expenses by categories of items in a multiple-rate VAT system, which helps reduce the duration of audit).

- A single rate also helps avoid permanent excess VAT credits for those enterprises subject to different rates for their purchases and sales. Refund claims can thus be restricted to exporters and investors.

In Francophone countries, significant progress is also needed to simplify VAT thresholds. Different thresholds often apply for the sale of goods and for the provision of services, and these thresholds are generally not applied to small businesses incorporated as legal entities.

${ }^{33}$ Bird and Gendron, The VAT in Developing and Transitional Countries (2007). 
Developing education and information programs. Most of the tax administrations in Francophone Africa now recognize the need to improve the quality of taxpayer services in order to facilitate tax compliance. ${ }^{34}$ Despite some resistance, the gradual emphasis on taxpayer services in traditionally audit-oriented tax administrations has had concrete results in some countries, including dissemination of tax brochures and posting of information on the tax administration's website (e.g., Côte d'Ivoire, Madagascar, and Senegal). A dialogue between the tax administration and its "customers" has also been initiated in some countries (e.g., Cameroon and Benin) during the budget preparation process and through ongoing consultations with business representatives to improve relations with the tax administration.

Despite this encouraging progress, major efforts are still needed in most Francophone countries, including further improvements in a number of basic areas, such as simplifying tax return and payment procedures, speeding up VAT refund processing for exporters and investors, and dealing with objections and appeals more efficiently and equitably.

Improving registration procedures. Assigning a reliable identifier to each taxpayer is a key component of any tax administration modernization strategy in order to develop a taxpayer master file and facilitate exchanges with Customs and other financial administrations. An effective taxpayer identification number system must meet three criteria:

- It must be a unique number assigned to a taxpayer for all tax purposes.

- It must be permanent. The same number is assigned to a taxpayer for as long as he/she is alive or his/her business remains in operation.

- Its use must be mandatory in dealing with Customs, participating in government contracts, and claiming VAT credits and refunds. In several countries, disclosure of the supplier's number is also mandatory on any invoice supporting a claim for business expenses.

Although all the tax administrations in the countries reviewed in this paper have now adopted a taxpayer identification number system (Table 3 above), twenty years after the first identifiers were introduced results still leave much to be desired. While today's taxpayer numbers no longer include components that may vary over time, separate numbers are still being used by other administrations (especially Customs) in some countries.

It also often takes several weeks or months for administrations to assign a taxpayer identification number; major improvements are needed to speed up the process without compromising integrity. Delays in updating files and removing large numbers of inactive files are additional weak points that can seriously hamper the use of computer systems, particularly for identifying and dealing with noncompliant taxpayers.

\footnotetext{
${ }^{34}$ For several years, this subject has been discussed in various conferences and seminars, particularly those organized by the CREDAF (Centre de rencontre et d'étude des dirigeants des administrations fiscales).
} 
Improving filing and payments procedures. Procedures for filing and payment on the basis of self-assessment often began with the old business turnover tax (TCA). They became widespread following introduction of VAT and have gradually been extended to the personal and corporate income taxes. These procedures, based on voluntary compliance, have sped up the payment of taxes by streamlining formalities and reducing opportunities for negotiation (Box 4).

Under the new procedures, taxpayers are expected to comply with their obligations with limited intervention of the tax administration. For this system to work, there must be proper education and information programs to ensure they understand their tax obligations, calculate the tax owed, complete the tax returns, submit them along with proper payment to the tax office, and stand ready to provide appropriate documentation to justify their tax returns in case of a tax audit. The spread of these procedures has been facilitated by the transfer of the tax collection function to the tax department in every country discussed in this paper, except for the Republic of Congo.

Despite this significant reform - which has sometimes been challenging — old practices (including the principle of the "separation of assessment and accounting functions" that was the basis for the split of responsibilities between the Tax Department and the Department of the Treasury and Public Accounting) have in some cases been maintained within the unified tax administration. For example, some countries have maintained a registration process (referred to as "regularization") that is no longer warranted. In addition, in a number of countries, delays in reforming the legal framework for tax collection result in inefficient and burdensome procedures for the tax offices and are an obstacle to modernizing tax payment methods, including, for example, payment of taxes through banks.

Moreover, major progress is still necessary in most countries to simplify tax return forms and eliminate obsolete practices which complicate taxpayer compliance and reduce the effectiveness and efficiency of the tax administration.

Box 6 presents some examples of bad practices for VAT administration that are still used in a number of countries. Simplifying procedures and gradually eliminating these bad practices are critical components of the reforms recently introduced in a number of tax administrations. 


\section{Box 6. Examples of bad practices in VAT administration}

\section{Examples}

\section{Documents to be attached to the VAT return. The}

requirement to attach a list of invoices (or sometimes copies of invoices) to the monthly VAT return is a costly burden for businesses, whether the information is to be presented electronically or in hard copy.

In principle, the objective is to process invoices using computer systems in an attempt to identify shortcomings in VAT returns. Despite anecdotal evidence (and the alleged deterrent effect of this requirement), the results have always been disproportionate to the considerable effort involved.

\section{Documentation to be attached to a $V A T$ refund}

claim, including copies of purchases and sales invoices and customs declarations with a view to conduct a systematic review. The lack of risk-based procedure to process exporters' and investors' refund claims is an obstacle to the functioning of VAT. It has the following negative consequences:

- It often takes several months to process claims, which severely undermines businesses' cash flow.

- Most pre-refund audits are pointless and do little to deter fraud and abuse. (In fact, experience shows that the quality of an audit is often inversely proportionate to the burden placed on businesses with unnecessary administrative requirements).

- There is a lack of confidence in the VAT system, and businesses try to lobby for exemptions and special treatments such as zero-rating systems for supplies to exporters (achats en franchise or suspension de TVA).

VAT withholding. In this system, VAT is collected in advance (précompte) by the Treasury and State-owned enterprises when a payment is made to a VAT registered supplier. While VAT withholding may have an initial positive impact in terms of revenue, it also results in serious cash problems for the suppliers.

Experience shows that this system also encourages significant abuses on the part of the "withholders," including delays in payment of the VAT withheld.

\section{Comments}

Modern tax administrations replace these intrusive and ineffective practices with selective, well-targeted cross-checking operations using risk management and computer systems, including the following:

- Regular cross-checking of purchases and sales of goods, and provision of services in sectors where risk of fraud have been identified.

- The search for information with potential to uncover unexplained wealth and unreported incomes (net worth, standard of living, lifestyle, etc.).

Adoption of risk management (in order to focus audits on those refund claims where risks have been identified) is essential to develop simplified refund procedures. This is fundamental to develop an efficient and effective VAT system. Until an appropriate computer system is in place, the following measures should help improve the processing of refund claims:

- Immediate processing of claims from businesses with a good track record with the tax and customs departments (e.g., filing and payment on time, no anomalies detected in previous audits that would indicate fraud and abuse, etc.).

- Pre-refund audit of invoices and recent returns using issue-oriented, well-targeted methods for all requests submitted by new businesses or by those with a track record showing obvious risks.

- Post-refund audit of claims that have been immediately processed, whether as part of a full audit for all taxes or an issue-oriented audit.

Withholding is incompatible with the functioning of a modern VAT. The principal argument to justify withholding is the risk of non compliance by small businesses. Obviously, the best approach is instead to adopt an appropriate registration threshold so that there is no need for VAT withholding.

Where government contracts are concerned, the best approach is to develop effective exchanges of information and to eliminate those businesses that fail to comply with their VAT obligations from the list of eligible government suppliers. 
IT support. There have been a number of positive IT changes in the tax administrations of developing countries and countries in transition in the past 10 years. These developments have been strongly influenced by technological change and new requirements expressed by users in the context of the modernization of the tax administration structures and procedures.

With the exception of Mali for the past 10 years and Senegal more recently, most of the 19 Francophone countries were unfortunately not able to benefit from these positive developments. Following the failure of the tax component of the Information Technology Program for Financial Administrations (PIAF) in the mid-1990s, ${ }^{35}$ some very basic applications were developed in Francophone Africa with limited resources (e.g., in Benin, Cameroon, Côte d'Ivoire, and Togo). However, these applications quickly reached their limits, and their performance has fallen short of the countries' expectations and needs.

The IT tools that need to be installed as part of a tax administration modernization strategy should meet three major requirements:

- Improving taxpayer services by providing on-line access to tax information as well as to tax forms and publications, and implementing on-line filing and payment procedures (at least, initially for the largest taxpayers).

- Improving tax operations, including the monitoring of returns and payments through a single taxpayer account, issuing reminder notices to noncompliant taxpayers, collecting tax arrears, creating databases and processing information, managing objections and appeals, and supporting introduction of risk management for the selection of files to be audited and the processing of VAT refund claims.

- Strengthening management and supervision of the tax offices, including developing a management information system and monitoring performance indicators.

Consistent with a predominant approach (Box 7), the solution adopted by Mali in the late 1990s and Senegal in $2008^{36}$ was to purchase a commercial off-the-shelf software package (COTS) that meets reasonably good IT standards.

\footnotetext{
${ }^{35}$ It had been expected that the taxation software of PIAF (Programme d informatisation des administrations financières - - which had been developed in Mauritania during the first half of the 1990s with significant technical assistance from France-would serve as a model for other Francophone countries.

${ }^{36}$ The Canadian International Development Agency (CIDA) provided technical and financial assistance to Mali in developing its tax computer system, while Senegal received support from the Investment Climate Facility for Africa (ICF). Installation of a software package is also being considered in Burundi with the assistance of the Department for International Development (DFID) of the United Kingdom.
} 


\section{Box 7. Tax administration computerization: Current trends}

The traditional approach of in-house development of IT systems aimed at addressing the specific needs of a particular country's tax administration is becoming less frequent, not only in developing and transition countries but also in some OECD countries. In developing countries, despite the high costs of the systems developed with that approach, experience has shown that the results have often fallen short of expectations. In the past 10 years or so, several tax administrations have purchased software package and adapted them to their specific needs. Software packages developed in the 1990s were designed to handle a specific type of tax, but most packages today are integrated IT systems designed to handle all types of taxes. The basic modules are registration, processing of returns and payments, issuance of reminders to noncompliant taxpayers, and collection of amounts owing, dispute management, and statistics.

Among the available software packages, those that have become the best known in the past 10 years are Bull eRIS (France) and CRC Sogema SIGTAS (Canada). SIGTAS has been installed, inter alia, in Caribbean countries, Kosovo, Lebanon, Rwanda, Mali, and Senegal, sometimes but not always with the support of the Canadian International Development Agency (CIDA). Bull e-RIS was first developed in several southern African countries but has since been installed in other countries, including Saudi Arabia and Egypt (under a USAID project). Other software packages currently available include the following: Oracle Enterprise Tax Management (ETM), purchased by Mexico, the Netherlands, the United Kingdom, and New Zealand; GENTAX, widely used in the United States at the state level and now Trinidad; SAP, which is notably used in Latin America, and for which installation was to begin in Algeria over two years ago with the assistance of a Spanish consultant; and Tax Solution, one of the oldest products, implemented in Latin America with the support of the Inter-American Center of Tax Administrations (CIAT).

The list is not exhaustive, but the proposed features of these packages are becoming more and more standardized due to competition among the suppliers. Further progress is still required in key areas relating to risk management, including support for audit selection and operations, and processing of VAT refunds.

In countries where such packages have been installed, deployment of the basic modules was initially expected to take 18 to 24 months, but this time-frame has often been exceeded. In fact, experience shows that a number of conditions, which have not always been adequately taken into account, need to be met in order to ensure successful computerization of the tax administration, particularly regarding the following:

- The software package has to be purchased as part of a tax administration's modernization strategy, including changes in the organizational structure and reengineering of the procedures. In the absence of a comprehensive strategy, any software package quickly shows its limitations. (This has been particularly evident in Mali since the late 1990s.)

- The timetable for installing a software package must be closely synchronized with the organizational and procedural changes. (In the case of Senegal, installation of basic computer modules before implementation of organizational and procedural changes has prevented the tax administration from taking full advantage of the capabilities offered by the IT package.)

- Ownership of the IT system and full use of its potential require major efforts to train users and help them understand the capabilities of the package. (Senegal and Mali, where such efforts were inadequate until very recently, illustrate this point as well.) 
Modernizing and improving the quality of audit. In a self-assessment system, once the tax administration has appropriately refocused its efforts to fully take into account taxpayers' services and education needs, modernizing tax audit programs and improving the quality of audit remain essential components of an effective compliance strategy.

In a modern tax system, audit selection and methods are based on risk management. Despite some resistance, the creation of large taxpayer offices in the countries discussed in this paper was a first positive step in improving the allocation of audit resources based on risks, with large taxpayer audit divisions being organized by industry (banking, insurance, trade, manufacturing, extractive industries, etc.). More recently, many of these countries have also set up medium-sized taxpayer offices, with specialized audit units. Allocating audit resources within these new structures should in itself help improve audit selection (based on identification of files for which a desk audit has revealed serious anomalies) and enhance responsiveness (by undertaking a field audit immediately for those returns where anomalies are identified).

Other progress is linked to improvements in audit methods, including the use of a several types of audits, beginning with improvements in desk audit (which is essential for field audit selection, especially in those tax administrations without adequate IT support). Several countries have also started issue-oriented audits (particularly for VAT), which enable them to react quickly by focusing on one or two returns where anomalies have been found during a desk audit. Box 8 summarizes the main components of an effective audit program.

Despite this encouraging progress, tax audit results in most of the 19 Francophone African countries still fall short of what is needed, especially in the following areas:

- Audit coverage is inadequate: less than 1 percent of large and medium-sized businesses are audited annually. ${ }^{37}$

- Desk audit programs need improvements and the use of issue-oriented audit methods is still inadequate in several countries, where the most frequent practice is still to conduct a full audit for all taxes due by of a given taxpayer and for several years.

- Collection of additional taxes due after an audit is inadequate, especially for the additional taxes due after a full audit (between 10 and 30 percent).

- The most serious cases of tax fraud and evasion are usually not prosecuted.

\footnotetext{
${ }^{37}$ From 1990 to 1993 , less than 100 tax audits were performed in 10 of the countries considered in this paper; that is, less than 1 percent of businesses that are subject to the standard (or normal) tax regime.
} 


\section{Box 8. The main components of a tax audit program}

A balanced audit program includes several components that need to be used depending on the anomalies and risks identified when returns are being processed, bearing in mind that how the work is organized, particularly for desk audits, is strongly influenced by the extent of the available IT support. The main components to be taken into account are the following:

- Desk audit. This includes (1) a check that the returns filed are consistent, (2) a comparative analysis of returns for different taxes, (3) a comparative analysis of the main ratios against those for similar businesses in the same sector, and (4) a cross-check against information received from other government agencies and third parties.

- Advisory visit. An advisory visit is intended primarily for newly created small and medium-sized businesses to (1) ensure the business is appropriately registered, and (2) confirm that it is well informed of its tax, accounting, and invoicing obligations.

- Issue-oriented audit. These audits are mainly conducted for VAT and payroll taxes. An issue-oriented audit should be limited to only one or two returns for a single tax. In the case of VAT, an issue-oriented audit may deal with all of the activities reflected in a tax return, or it may focus on one particular aspect (e.g., turnover, exports, invoicing, or credit).

- VAT refund audit. This is a specific kind of issue oriented audit performed prior to a VAT refund (in principle, only for a small number of cases selected according to risk analysis criteria: see Box 6).

- Full (or comprehensive) audit. Where significant anomalies are detected through a desk or issue-oriented audit, such cases should be selected for a full audit of all taxes, initially for only one year. If these anomalies are confirmed, the audit may be expanded to entire time period not subject to a statutory limitation.

- Verification of personal income. In case of particularly serious anomalies and fraud, an in-depth verification of the managers' income tax returns may be warranted. This is particularly the case where turnover has been underreported and unexplained wealth is suspected.

- Tax fraud investigation. In the most serious case of fraud, which are confirmed by a full audit and verification of the manager's incomes, the file should be referred to a specialized unit responsible for criminal investigations. These investigations are usually conducted under control of the judiciary.

Despite significant assistance provided, over several years, in the areas of audit training and audit policy design, significant progress is still needed in many tax administrations of Francophone Africa to develop an audit strategy suitable for the needs of a modern tax system. Given the progress achieved in restructuring the tax office network and an increased acceptance for diversifying audit methods, efforts should now focus on three areas:

- Strengthening (or establishing) the headquarters unit (or division) responsible for audit policy and methods, and supervision of audit programs.

- Enhancing the use of intelligence and cross-checking operations to improve audit selection.

- In those countries able to acquire and install a software package, developing specific modules for risk management and tax audit. 


\section{ASSESSMent OF Reforms AND MaIn Challenges to Be ADDRESSED}

This chapter provides an assessment of the reforms implemented over the past 15 years in the tax administrations of the 19 Francophone countries of sub-Saharan Africa. It shows positive aspects while highlighting areas where progress is needed and shortcomings that require priority actions to improve the tax administrations' performance and cope with the main challenges that they need to address in a frequently difficult context.

\section{A. Domestic Tax Revenues}

To begin this chapter on a positive note, the large increase of domestic tax revenues in most of the 19 countries since the mid-1990s is encouraging (Table 4). While the impact of tax administration reforms is difficult to quantify, it is obvious that changes - such as the successful adoption of VAT and creation of large taxpayer offices that are often responsible for more than 70 percent of domestic tax collections - have contributed to this progress.

Table 4. Trends in domestic tax revenues, 1995 to 2008

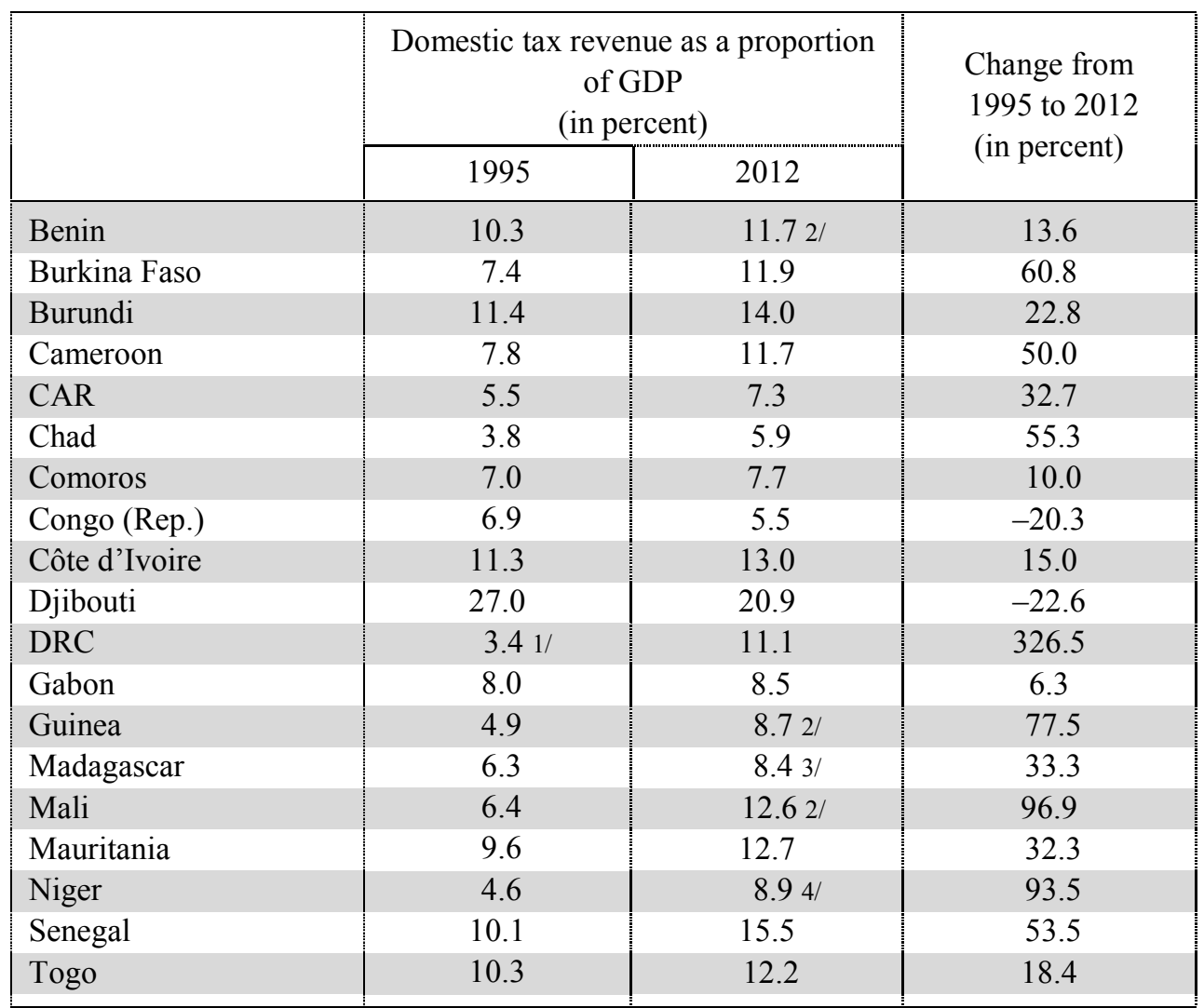

Source: IMF

1/ This figure is from 1999. No data available for 1995-1998;

$2 /$ data for 2010

$3 /$ data for 2008 ;

4/ data for 2011. 
Except for two countries (Djibouti and the Republic of Congo) where the change in revenue is negative, the domestic tax revenue increase is particularly important:

- 15 percent-25 percent in Burundi, CAR, Côte d'Ivoire, and Togo.

- 25 percent -50 percent in Cameroon, Chad, Madagascar, and Mauritania.

- 50 percent-100 percent in Burkina Faso, Guinea, Mali, Niger, and Senegal.

- Over 300 percent in DRC whose performance is largely explained by the end of the civil conflict.

This increase in domestic revenue has offset the loss of customs revenue and boosted the growth of government resources that was particularly weak in the 1980s and early 1990s, especially in the CFA franc area.

\section{B. Assessment of Reforms}

Annex 1 analyzes positive aspects and those where further progress is needed in the 19 tax administrations examined in this paper. The main key points are summarized below.

Main areas of success. During the 15 years of reforms supported by the IMF and other development partners, the main achievements have been as follows:

- VAT has been successfully introduced in 18 countries.

- Tax codes, including tax procedure codes, have been adopted in 4 countries and similar initiatives are under way in several other countries.

- In the 19 countries, tax administrations now have a unified organizational structure covering all taxes and all tax functions.

- Segmentation has been introduced in the operational offices of all tax administrations, starting with establishment of large taxpayer offices.

- All tax administrations have introduced - not without a number of difficulties - the principle of voluntary compliance, beginning with adoption of self-assessment procedures for filing and payment.

- Taxpayer identification numbering systems have been implemented in all countries.

- Strengthening taxpayer services and taxpayer education programs are becoming, gradually, key components of the modernization strategies of these administrations.

- Creation of large taxpayer offices has resulted in some progress in the organization of the audit function and in many countries initiatives are under way to diversify audit methods.

- The French government and the CREDAF, and more recently the AFRITACs, have provided significant support in training tax officers. 
- The large amount of technical assistance resources made available by several development partners confirms an ongoing interest in supporting tax administration reform in the 19 Francophone countries of sub-Saharan Africa.

Areas where further progress is needed. Consolidating the achievements will require additional measures to broaden and deepen reforms in the following areas:

- Strengthening VAT legislation and operations requires: (1) maintaining a single VAT rate; (2) adopting a single VAT threshold and applying it to all businesses, including corporations; (3) simplifying filing procedures (e.g., repealing the requirement to provide a list or copies of invoices) and payment procedures (e.g., eliminating VAT withholding); and (4) speeding up the processing of refund claims.

- Modernization of the tax administration and that of those units responsible for non-core revenue functions such as property registry (cadastre) and management of public properties (domaines), require an in-depth study to design an optimal organizational structure for performing these non-core revenue functions, including the transfer of these functions to a specialized agency.

- A more aggressive approach is often required to completing the transfer of the tax collection function to the tax administration, including (1) modernizing and simplifying payment procedures; and (2) strengthening collection enforcement.

- In the short term, consolidating the organization based on taxpayer segmentation requires (1) strengthening large taxpayer offices; and, as needed, (2) establishing medium-size taxpayer offices in major centers.

- Over the longer term, further developing segmentation will require (1) adopting simplified, effective and efficient tax regimes for small and micro-enterprises, and (2) reorganizing the structures and procedures of the offices dealing with these taxpayers.

- Strengthening voluntary compliance requires major changes in the tax administrations culture and methods, including: (1) installing software packages to support modernization of taxpayer services and audit; and (2) introducing risk management.

- The taxpayer identification number should be the primary identifier for Customs and other government agencies to facilitate the sharing of information with the tax administration and to simplify business registration.

- Further improvements in taxpayer services must take into account the needs of the different segments. One high priority in this area is to speed up the processing of VAT refunds as well as objection and appeal procedures.

- In most countries, consolidating voluntary compliance requires major improvements in the audit function, including: (1) strengthening audit policy design and supervision, 
(2) improving monitoring of audit results (including quality of audit), (3) refocusing the current central audit (operational) directorates on intelligence and fraud investigations, and (4) further diversifying audit methods.

- Strengthening human resource management requires additional effort in staff training and development, reducing corruption, and reform of the bonus and incentive systems.

- Implementation of an approach combining development of strategic management and the use of performance contracts (similar to the approach recently carried out in Senegal) would test - and may confirm - the capacity of governments in Francophone countries to provide their tax administration with the necessary flexibility in managing their resources, which is crucial to their modernization.

- The Francophone countries' tax administrations should consider establishing change management structures (similar to the modernization unit recently created in Senegal).

\section{There are serious shortcomings which should be urgently addressed with the support of development partners. These are listed below:}

- The scope of exemptions, particularly VAT exemptions, remains a major concern in the countries of Francophone Africa, especially for those exemptions covering entire sectors (e.g., agriculture, fishing, mining, and oil). Implementation of tax expenditure analysis (as in Senegal) would help increase policy makers' awareness of this problem.

- Moreover, exemptions on aid are by definition very important in countries where the capacity to cope with the negative consequences of these exemptions is the weakest.

- Priority actions are also needed to strengthen tax administration headquarters in line with the proposals discussed earlier in this paper (Chapter III) in order to strengthen management capacities in the areas of policy design and supervision of programs to be implemented by the operational offices.

- Despite progress achieved with the creation of large taxpayer offices and medium-size taxpayer offices, the fragmentation of the tax office network and, sometimes, the multiple layers of management (for example, at the departmental, regional, and central levels), remains a matter of concern which require more innovative approaches to improve the efficiency of the tax administration.

- In most countries, the lack of adequate intelligence capacity requires priority actions to improve audit selection and broaden the tax base. Modernization of intelligence activities and processing of information requires basic IT tools (including, as needed, temporary systems pending the future installation of an integrated software package).

- Delays in installing IT systems in the 19 Francophone countries' tax administrations hamper the modernization of these tax administrations, including introduction of risk management. Installation of an integrated IT system is a key component in a tax 
administration modernization strategy. Installation of the system must be closely coordinated with implementation of the organizational and procedural changes, and proper preparation of the users is needed to ensure they will take full ownership of the system.

- Despite the number of agencies that have been involved in providing technical assistance to the tax administrations of the 19 Francophone countries, the experience of these countries with modernization projects covering all the key areas - including strategy design, organizational and procedural reforms, IT, and human resources-lags behind that of many other African countries. Continued coordination among development partners and the design of appropriate technical assistance programs are essential to launch the necessary initiatives. Priority should be given to those countries where success factors have been identified, particularly a government's sustained commitment to support tax administration modernization (see Chapter V).

\section{The Main Challenges}

The political and social context is a decisive factor for the successful operation of a tax system based on voluntary compliance, including, in particular, the quality of institutions, the degree of maturity of the political system, integrity of policy makers, transparency in public expenditure management, and, of course, a fair distribution of the tax burden. Until the desired progress materializes, the political and social context of several countries discussed in this paper will inevitably undermine the modernization of the tax administration.

Besides a context upon which tax administrators and technical experts have little influence, other significant challenges will need to be overcome to modernize these tax administrations. These challenges include a lack of flexibility in the governance framework of many Francophone tax administrations and the inadequate experience of these administrations with project management. These are particularly important in light of the conclusions of this study and the experience gained during a number of IMF technical assistance missions over the past $15-20$ years.

Modernizing the tax administrations' governance framework. As a legacy of the colonial era, the 19 Francophone countries of sub-Saharan Africa have retained the traditional governance framework - a directorate which is typically part of the finance or budget ministry - with the exceptions of Burundi and Togo. ${ }^{38}$

In countries with a strong tradition of centralization, the experience of the tax administrations considered in this paper shows this traditional governance framework has a number of drawbacks, particularly in terms of lack of flexibility in managing budget and human

\footnotetext{
${ }^{38}$ In 2009, Burundi restructured its tax administration by setting up a semi-autonomous revenue agency modeled on that of most other English-speaking African countries. The Burundian Revenue Service (OBR or Office burundais des recettes) was established in conjunction with Burundi's entry into the East African Community, with significant support from the Department for International Development (DFID) of the United Kingdom. The OBR is responsible for tax and customs administration. The Togolese authorities plan to set up a Revenue agency, based on the OBR's organizational structure, by end-2013.
} 
resources (that are subject to the civil service rules) and their organizational structure (with each office's organization chart being typically designed by the finance ministry and the civil service ministry across the whole of the public administration). This lack of flexibility is often amplified by a strong centralization of decision-making powers, including in extreme cases the requirement for the minister of finance's signature for basic procedures (e.g., approval of tax register and tax refunds, and decisions regarding appeals and objections).

To address these problems, some Francophone tax administrations have signed a "performance contract" with the minister of finance. The preparation of such a contract is normally preceded by the development of a corporate (or strategic) plan with well-identified objectives - such as improving taxpayer services and improving quality of tax audits — and performance standards to measure the extent to which these objectives are achieved — such as findings from taxpayer surveys, and improvement of audit selection measured in terms of increased collection performance and reduction in the number of objections and appeals following audits. While the tax administration commits itself to achieving these strategic goals and performance standards, the government agrees to provide appropriate support, for instance increased budget flexibility (e.g., carrying over unused annual appropriations) and additional resources (e.g., installation of a software package, performance bonuses, etc.).

Among the few countries that have taken this approach, Senegal, where an ambitious tax administration modernization project has recently been developed, is an encouraging example. However, this country's experience shows that the materialization of the government commitment can be particularly difficult in a developing country. ${ }^{39}$ Whatever the governance framework developed for the tax administration, experience shows that it is crucial for this administration to have sufficient flexibility to carry out its functions while benefiting from a sufficiently strong and ongoing political support. ${ }^{40}$ Indeed, the lack of flexibility evident in this area in Francophone African countries is an obstacle to human resource development and may often demoralize even the most highly motivated staff.

Without necessarily recommending that the semi-autonomous revenue agency model—which is increasingly found in many countries, particularly in Anglophone Africa and Latin America - should be replicated, it is essential that initiatives be taken in the Francophone countries to develop a governance framework that facilitates a sustainable modernization of the tax administration - including provision of more flexibility in managing resources and in designing organizational structures. In the coming years, experience will show if the performance contract approach offers a credible alternative. In those countries where the main success factors are in place, this approach could be combined with implementation of a tax administration modernization project supported by development partners.

\footnotetext{
${ }^{39}$ For example, in this case, it has not been possible to conduct the planned taxpayer surveys that were needed to measure progress in the areas of education and services. Moreover, the government has not yet been able to provide additional resources to support the modernization of the tax administration as provided for in the 200912 performance contract.

${ }^{40}$ Crandall and Kidd, Revenue Administration: A Toolkit for Implementing a Revenue Authority (April 2010).
} 


\section{Strengthening preparation and implementation of the tax administration modernization projects. Comparison of the tax administration reform approaches used in the countries discussed in this paper shows large differences among them; however, one common characteristic for most of them is a lack of experience in project design and implementation.}

Approaches to reform are influenced by culture, traditions, and by the governance framework not only of the tax administration but also of the development agencies. Thus, in those countries where a semi-autonomous agency has been created (often with the support of the World Bank and the development agencies of the United Kingdom or the United States) the overriding approach is characterized by a capacity building partnership between the government and the agencies to provide joint financing for an appropriate modernization budget that will support project execution.

In this approach, the development agency undertakes a feasibility and risk assessment study. Once the project is approved, a consulting firm is selected, usually through a bidding process. The financial and technical resources provided through this type of assistance may vary, but the main components typically cover the modernization of organizational structures and procedures, installation of a software package, development of human resources, purchase of equipment, and sometimes renovation of office facilities. The positive result of this approach is the possibility to secure substantial capacity building resources and to strengthen project governance. In most countries, the development agencies ensure that the tax administration is given enough flexibility in budget and resource management to enable the project to succeed. ${ }^{41}$ The main drawback is the length of project preparation, often more than a year after completion of the feasibility and risk assessment study and design of the modernization strategy.

On the other hand, the approach typically adopted in Francophone African countries concentrates the supervision of reforms in the ministry of finance with varying degrees of technical and financial support from development agencies (especially those financed through the European Union and French government, but also sometimes World Bank and Canadian government, as well as the Japanese government, the latter for the financing of IMF experts: Chapter I, Table 2). Under this approach, each agency focuses on one specific area and organizes its expert missions in agreement with the minister of finance. ${ }^{42}$

In addition to the secondment of French government officials as resident advisors to the minister of finance or to the director of the tax administration, expert missions organized by various development agencies are usually short visits focusing on a specific area that were

\footnotetext{
${ }^{41}$ This approach has been followed in modernizing tax administration in a number of countries, including among others, Egypt, Malawi, Uganda, Rwanda, Tanzania, and recently Burundi.

${ }^{42}$ As indicated in Chapter I, whatever the approach taken by the government, the IMF also organizes expert missions at the request of the minister of finance to review the tax administration and to help develop reform strategies. Depending on the extent of the reforms and the country's needs, these missions can be supplemented by follow-up expert visits (organized by IMF headquarters or the AFRITACs) to support implementation of the reforms in coordination with other development partners.
} 
previously agreed to between the agencies and the government. The drawback to this piecemeal approach is that coordination may be difficult, the quality of experts' work may not be adequately monitored, project governance may be weak, and - most importantly - the resources provided may be inadequate to cover all aspects of the modernization strategy. Political instability, or the change of minister of finance or director of the tax administration, may also pose serious risks to the successful implementation of reforms.

Based on the assessment of the reforms implemented and the authors of this paper's experience with tax administration reforms, it is clear that more effective coordination among development partners and well-designed technical assistance programs, are highly desirable to strengthen capacity building. Also required are the mobilization of appropriate resources and preparation of budgets covering all aspects of the tax administration reform strategies.

This kind of cooperation - with a strong focus on capacity building instead of multiplication of short and long-term expert visits - would promote development of more effective project governance structures, including stronger supervision of consultants who should be selected on the basis of a transparent bidding process. This would facilitate implementation of comprehensive modernization projects for which the main success factors are discussed in the following chapter. 


\section{Conclusion: The MaIn SuCCess Factors}

Comparing the situation of the various Francophone African countries regarding tax administration reform vis-à-vis the situation of other sub-Saharan African countries shows that, overall, the Francophone countries have well understood and assimilated the fundamental concepts in their reform strategies.

This is particularly true, for instance, regarding VAT implementation, merger of all domestic tax operations within a single tax administration, introduction of segmentation and creation of the first large taxpayer offices and medium taxpayer offices, and development of simplified taxation regimes for small and micro-enterprises. All these measures had already been included in the tax administration reform plans of many of the Francophone African countries in the early 1990s, that is ten years or more before the same concepts were included in the reform plans of other tax administrations in Africa.

\section{However, despite this advance at a conceptual level, the situation in terms of successful implementation of the tax administration reform shows that Francophone countries are} lagging behind many other African countries. Several reasons can be identified to explain this situation. Several possible factors were discussed in the previous chapters, including, for example, the difficult political and social context. However, this is equally true for several non-Francophone African countries where major reforms have been implemented successfully in spite of particularly challenging political and social circumstances. ${ }^{43}$

More likely explanations for the temporary setbacks and delays in implementing tax administration reforms in Francophone Africa can be found by analyzing the factors that have enabled other countries to institute those reforms successfully. In light of the issues discussed in the previous chapters of this paper, several of these success factors are obviously not present yet in several of the 19 Francophone countries and this list could be seen as general guidelines to be followed by these countries' governments and development partners.

\section{International experience shows that the main success factors of tax administration reforms are as follows:}

1. An unequivocal commitment of policy makers and the minister of finance to support the reforms, from the start of the project throughout its successful completion.

2. Capacity to adopt and implement the necessary legislative changes.

3. The motivation and leadership skills of the tax administration's managers.

\footnotetext{
${ }^{43}$ This was true, for example, in Rwanda following the genocide and in Uganda where the political situation remains difficult. Despite these difficulties, an effective use of the technical and financial support provided by the World Bank and DFID have enabled these countries to structure their tax administrations as revenue agencies in which major organizational and procedural reforms were implemented, including installation of software packages and effective human resources programs. Less than ten years after the launch of these reforms, the Rwandan and Ugandan tax administrations are now recognized as models for others in Africa.
} 
4. Definition of a vision for a modern tax administration and development of a welldesigned reform strategy with detailed action plans covering all aspects of the strategy.

5. The ability to mobilize the human resources that are needed to implement the reforms, including high-skill project managers and proactive, motivated project teams.

6. Mobilization of the budget resources and external financing that are indispensable for implementing reforms.

7. Establishment of an effective project governance structure, including: (1) a steering committee at the appropriate level, (2) strategic management of the reforms with milestones and performance indicators, and (3) transparent procedures for recruiting consultants and purchasing a software package and equipment.

8. Effective coordination of technical and financial assistance made available by the development partners (including, where appropriate, an agency taking a leadership position). Participation of the development partners in the steering committee meeting should also be considered.

9. Ongoing supervision and quality control of the work done by the experts and consultants selected through the bidding process by the government.

10. An internal and external communications plan to facilitate implementation of the modernization project and keep all stakeholders informed (e.g., general public, business and accountant representatives, other government agencies, as well as tax office managers and staff representatives).

11. Close coordination between the project structure (project managers and teams) and the main headquarters units (or divisions) of the tax administration.

12. Establishment of a "change management office" should help strengthen this coordination (by integrating the process of change in the tax administration's permanent structures) and the strategic management of the reforms.

13. A strong ownership of the tax administration's staff and its commitment to implementation of all the reforms. This should be facilitated by the communications plan and a comprehensive human resource development program, including training and career planning for office managers and staff members.

14. Adoption of a performance contract covering the period of the project implementation could be another factor of success in Francophone countries as a guarantee (to the tax administration and the development partners) that the government will provide the necessary ongoing support. While the contract would set out the tax administration' commitments in terms of performance and implementation of the modernization strategy, the government would commit itself to the following:

- Providing the tax administration with the necessary funding to carry out the project. 
- Providing the tax administration with sufficient flexibility to manage its budget and human resources effectively.

- Giving the tax administration the necessary autonomy to modernize its organizational structures at headquarters and in the field offices.

This list of factors of success is not exhaustive, and the order in which they are presented is not necessarily appropriate in all countries. Nevertheless, these factors certainly represent a consistent foundation for successful implementation of reforms, encompassing: (1) good leadership and management; (2) the critical need for flexibility in the management of the budget and resources, and (3) the critical need for a well coordinated - and effectively used - technical and financial assistance. As shown in the previous chapters of this paper, these are clearly major challenges that are facing tax administrations of the 19 Francophone countries of sub-Saharan Africa. 
Annex 1. Assessment of the reforms implemented since 1995

\section{by the tax administrations of the Francophone countries of sub-Saharan Africa}

\begin{tabular}{|c|c|c|c|}
\hline & Main areas of success & Areas where further progress is needed & $\begin{array}{c}\text { Serious shortcomings that require } \\
\text { priority attention }\end{array}$ \\
\hline \multirow[t]{2}{*}{$\begin{array}{l}\text { 1. Simplifying tax } \\
\text { legislation }\end{array}$} & $\begin{array}{l}\text { VAT: The successful adoption of } \\
\text { VAT in } 18 \text { of the } 19 \text { Francophone } \\
\text { countries is an unquestionable } \\
\text { success. The relative simplicity of the } \\
\text { legislation (single rate) and the } \\
\text { quality of the preparations are two } \\
\text { main reasons, among others, for this } \\
\text { success. }\end{array}$ & $\begin{array}{l}\text { Areas where further progress is still needed to } \\
\text { consolidate the performance of VAT include } \\
\text { the following: } \\
\text { - Simplifying the registration threshold by } \\
\text { setting a single, sufficiently high threshold. } \\
\text { This should apply to all businesses whether } \\
\text { or not they are incorporated as legal } \\
\text { entities. } \\
\text { - Eliminating bad practices for filing and } \\
\text { payment by repealing the requirements for } \\
\text { lists or copies of invoices, and eliminating } \\
\text { VAT withholding. } \\
\text { - Speeding up the processing of refunds by } \\
\text { using risk management to identify the } \\
\text { claims to be audited prior to refund. } \\
\text { - Maintaining a single VAT rate, combined } \\
\text { with (1) mechanisms to provide financial } \\
\text { assistance to the poorest families, and (2) a } \\
\text { reduction of the single VAT rate if budget } \\
\text { resources permit. }\end{array}$ & $\begin{array}{l}\text { Exemptions disrupts the functioning of the VAT } \\
\text { in the countries examined: } \\
\text { - Broadening the tax base to include all sectors } \\
\text { (including natural resources) and eliminating } \\
\text { special schemes providing for suspension of } \\
\text { VAT are particularly urgent. } \\
\text { - In the longer term, it is essential to broaden } \\
\text { the VAT base to include basic food items } \\
\text { (while developing proper mechanisms to } \\
\text { provide financial assistance to the poor). } \\
\text { Other initiatives are needed to help policy } \\
\text { makers and development agencies appreciate the } \\
\text { extent of the revenue losses and disruption } \\
\text { resulting from VAT exemptions, including the } \\
\text { following: } \\
\text { - Establishing tax expenditure analysis to assess } \\
\text { forgone tax revenue (based on the work done } \\
\text { in Senegal). } \\
\text { - Concerted action by development agencies to } \\
\text { eliminate exemptions on aid (following the } \\
\text { World Bank's recent approach). }\end{array}$ \\
\hline & $\begin{array}{l}\text { Adoption of tax codes, including tax } \\
\text { procedure codes with support from } \\
\text { France (particularly in Benin, } \\
\text { Cameroon, Gabon, and Mali). }\end{array}$ & $\begin{array}{l}\text { Work is under way to prepare tax codes in } \\
\text { several other countries as well (particularly in } \\
\text { Niger and Senegal). }\end{array}$ & \\
\hline
\end{tabular}




\begin{tabular}{|c|c|c|c|}
\hline & Main areas of success & Areas where further progress is needed & $\begin{array}{l}\text { Serious shortcomings that require } \\
\text { priority attention }\end{array}$ \\
\hline \multirow[t]{2}{*}{$\begin{array}{l}\text { 2. Modernizing the } \\
\text { organizational } \\
\text { structure of the tax } \\
\text { administration }\end{array}$} & $\begin{array}{l}\text { Integrating direct tax, indirect tax, } \\
\text { and stamp duty operations within a } \\
\text { unified tax administration: This } \\
\text { reform has been successfully } \\
\text { implemented in the } 19 \text { Francophone } \\
\text { countries. }\end{array}$ & $\begin{array}{l}\text { When the different types of taxes were } \\
\text { merged, the land registry and public property } \\
\text { management functions were also included in } \\
\text { the new, unified tax administration (except in } \\
\text { Madagascar and Mali). } \\
\text { Experience shows that keeping non-core } \\
\text { revenue functions within the tax } \\
\text { administration impedes the tax } \\
\text { administration's modernization, and } \\
\text { complicates the modernization of these non- } \\
\text { core revenue functions as well. It would be } \\
\text { more effective and efficient to handle the land } \\
\text { registry and public property management } \\
\text { functions in a specialized agency (while } \\
\text { maintaining proper exchanges with the tax } \\
\text { administration for local tax operations). } \\
\text { The countries where these non-core revenue } \\
\text { functions have been maintained in the tax } \\
\text { administration should consider transferring the } \\
\text { land registry and public property management } \\
\text { functions to a specialized agency in order to } \\
\text { refocus the tax administration on its core } \\
\text { functions. This initiative would allow a better } \\
\text { use of the available resources for modernizing } \\
\text { these two separate lines of business. }\end{array}$ & $\begin{array}{l}\text { Weakness of headquarters: this is an area where } \\
\text { recommendations have not thus far been } \\
\text { properly acted upon. There are many areas } \\
\text { where problems are evident: } \\
\text { - Operational functions are often handled by } \\
\text { headquarters. } \\
\text { - There is inadequate delegation of powers. } \\
\text { - Key functions are fragmented (and hence } \\
\text { responsibilities are diluted) among too many } \\
\text { headquarters units. } \\
\text { - It is difficult to recruit and motivate high-skill } \\
\text { staff for headquarters. } \\
\text { - There is a lack of reliable information } \\
\text { regarding the activities of the operational } \\
\text { offices. } \\
\text { In all these cases, the following consequences } \\
\text { are inevitable: } \\
\text { - The ability to design policies and compliance } \\
\text { programs and to supervise the activities of the } \\
\text { operational offices is compromised. } \\
\text { - It is difficult to design and manage tax } \\
\text { administration reforms. }\end{array}$ \\
\hline & $\begin{array}{l}\text { Transferring all tax collection } \\
\text { functions to the tax administration: } \\
\text { This reform, which was often } \\
\text { difficult, has been successfully } \\
\text { implemented in } 18 \text { of the } \\
19 \text { Francophone countries. }\end{array}$ & $\begin{array}{l}\text { Resistance to this reform has been especially } \\
\text { strong in some countries. Major progress is } \\
\text { still essential to take full advantage of the } \\
\text { transfer of responsibilities, particularly in the } \\
\text { following areas: } \\
\text { - Modernizing payment methods (such as } \\
\text { allowing payments to be made directly to }\end{array}$ & \\
\hline
\end{tabular}




\begin{tabular}{|c|c|c|c|}
\hline & \multirow[t]{2}{*}{ Main areas of success } & Areas where further progress is needed & $\begin{array}{l}\text { Serious shortcomings that require } \\
\text { priority attention }\end{array}$ \\
\hline & & $\begin{array}{l}\text { banks or on-line) and, where necessary, } \\
\text { clarifying the legal framework. } \\
\text { - Strengthening collection enforcement, } \\
\text { particularly in the case of additional } \\
\text { assessments following a tax audit. }\end{array}$ & \\
\hline & $\begin{array}{l}\text { Introducing segmentation in the } \\
\text { organizational structure and } \\
\text { operations of the field offices, } \\
\text { beginning with the establishment of } \\
\text { LTOs. Despite some resistance, this } \\
\text { reform has been successfully } \\
\text { implemented in most countries. }\end{array}$ & $\begin{array}{l}\text { Segmentation needs to be strengthened with } \\
\text { the following aims: } \\
\text { - To continue strengthening the LTOs. } \\
\text { - To consolidate medium-sized taxpayer } \\
\text { offices (MTOs) in major cities. The } \\
\text { purpose of the MTOs is to administer } \\
\text { businesses whose turnover is above the } \\
\text { VAT registration threshold. } \\
\text { - To establish simplified, effective tax } \\
\text { regimes for small businesses (i.e., those } \\
\text { whose turnover is below the VAT } \\
\text { threshold) by setting up specialized offices } \\
\text { to administer the tax obligations of small } \\
\text { businesses. }\end{array}$ & $\begin{array}{l}\text { The complexity and fragmentation of the field } \\
\text { office network and the tendency toward an } \\
\text { unnecessary proliferation of supervisory levels } \\
\text { continues to be a matter of concern in several } \\
\text { Francophone countries. In conjunction with } \\
\text { setting up LTOs and MTOs, work still needs to } \\
\text { be done in the following areas: } \\
\text { - Where necessary, merging tax offices and } \\
\text { using small outlets or service units to provide } \\
\text { basic information and specific services (e.g., } \\
\text { sale of revenue stamps) in remote locations. } \\
\text { - Eliminating unnecessary supervisory levels } \\
\text { (including the overlapping of departmental } \\
\text { and regional directorates). }\end{array}$ \\
\hline $\begin{array}{l}\text { 3. Strengthening } \\
\text { voluntary } \\
\text { compliance }\end{array}$ & $\begin{array}{l}\text { Implementation of self-assessment } \\
\text { procedures for filing and payment: in } \\
\text { the } 19 \text { Francophone countries, these } \\
\text { procedures, which often started with } \\
\text { the old business turnover taxes, have } \\
\text { been successfully expanded } \\
\text { following adoption of VAT. }\end{array}$ & $\begin{array}{l}\text { Introducing new filing and payment } \\
\text { procedures is only one step in the transition to } \\
\text { a voluntary compliance system. In order for } \\
\text { this system to function properly, there must be } \\
\text { a substantial change in the culture and } \\
\text { working methods of tax administrations. } \\
\text { Major efforts in this area are essential in the } \\
19 \text { Francophone countries, with particular } \\
\text { reference to the following aspects: } \\
\text { - Improving taxpayer education and services, } \\
\text { including simplification of procedures and }\end{array}$ & \\
\hline
\end{tabular}




\begin{tabular}{|c|c|c|}
\hline Main areas of success & Areas where further progress is needed & $\begin{array}{c}\text { Serious shortcomings that require } \\
\text { priority attention }\end{array}$ \\
\hline & $\begin{array}{l}\text { use of modern payment methods (see } \\
\text { below). } \\
\text { - Strengthening the quality and effectiveness } \\
\text { of audit (see below). } \\
\text { - Installing integrated IT systems with a view } \\
\text { to improve taxpayer services, collection } \\
\text { enforcement, audit, and all other key tax } \\
\text { administration functions (see below). } \\
\text { - Introducing risk management in all aspects } \\
\text { of the tax operations, including audit. } \\
\text { Efforts are also needed in a number of } \\
\text { countries to eliminate the obsolete enrollment } \\
\text { procedures for the profit tax and corporate tax. } \\
\text { Moreover, the bad practices discussed in the } \\
\text { paper in reference to the VAT need to be } \\
\text { eliminated in order to improve the operations } \\
\text { of the voluntary compliance system. }\end{array}$ & \\
\hline $\begin{array}{l}\text { Taxpayer registration: A taxpayer } \\
\text { identification number (TIN) system } \\
\text { has been successfully implemented in } \\
\text { the } 19 \text { Francophone countries. }\end{array}$ & $\begin{array}{l}\text { Getting the customs department and other } \\
\text { government offices to use the TIN-and to } \\
\text { stop using other identification numbers-is a } \\
\text { priority to improve the sharing of information } \\
\text { and to simplify businesses' obligations. }\end{array}$ & \\
\hline $\begin{array}{l}\text { Improving taxpayer services and } \\
\text { education: The importance of this } \\
\text { function is now recognized by most } \\
\text { of the } 19 \text { Francophone countries. }\end{array}$ & $\begin{array}{l}\text { Establishment of specialized offices for the } \\
\text { various segments of taxpayers must go hand } \\
\text { in hand with well-targeted taxpayer services } \\
\text { and education programs aimed at addressing } \\
\text { the needs of these taxpayers more effectively. } \\
\text { Once procedures have been simplified, } \\
\text { modernizing registration, filing, payment, and } \\
\text { refund procedures will require installation of }\end{array}$ & \\
\hline
\end{tabular}




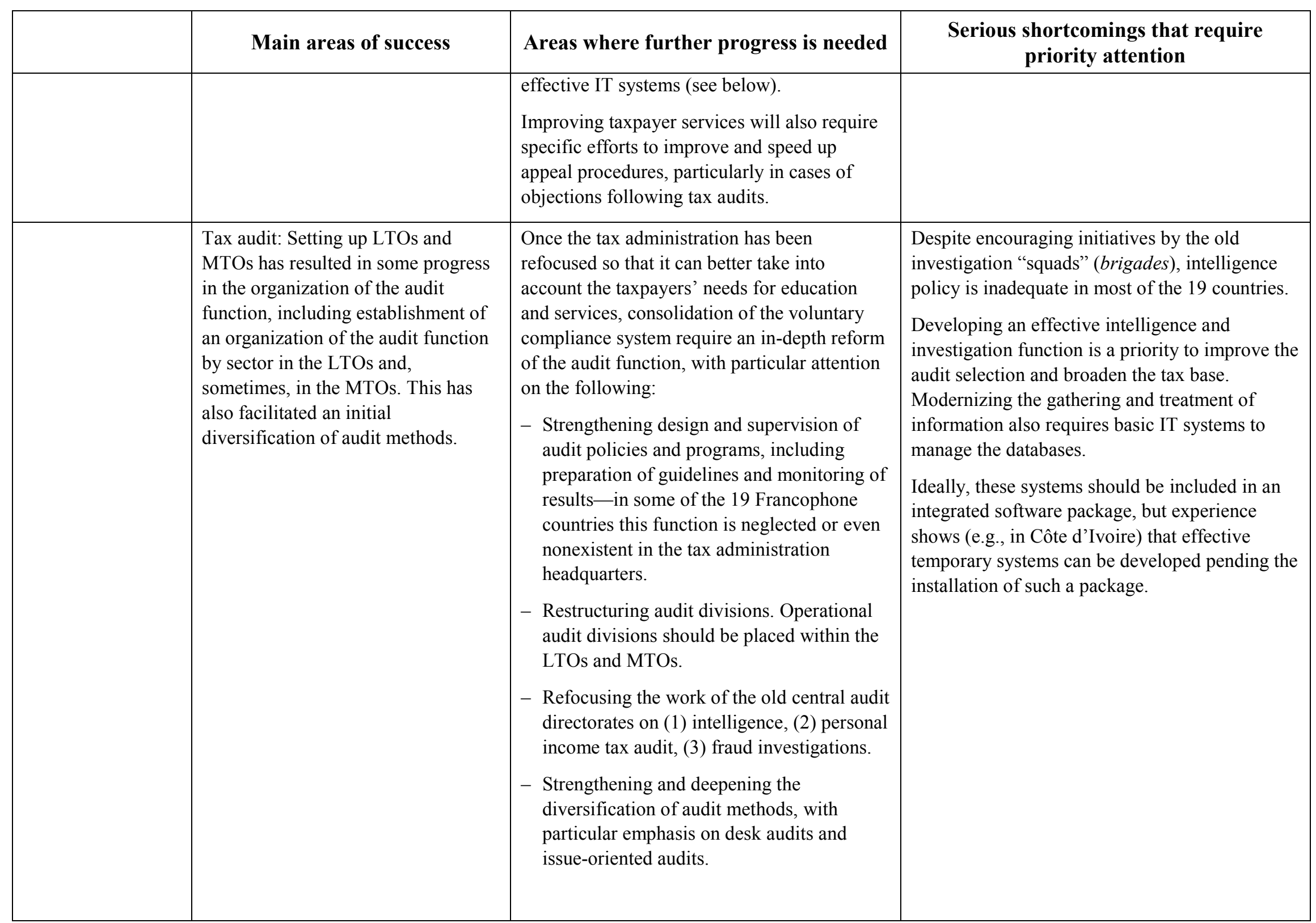




\begin{tabular}{|c|c|c|c|}
\hline & Main areas of success & Areas where further progress is needed & $\begin{array}{c}\text { Serious shortcomings that require } \\
\text { priority attention }\end{array}$ \\
\hline $\begin{array}{l}\text { 4. Implementing a } \\
\text { tax administration } \\
\text { computer system. }\end{array}$ & & & $\begin{array}{l}\text { Despite the progress that can be seen in a } \\
\text { number of developing countries, the obvious } \\
\text { delays in installing effective and efficient } \\
\text { IT systems in the tax administrations of the } \\
19 \text { Francophone countries are an obstacle to } \\
\text { (1) modernizing the tax administration, and } \\
\text { (2) developing risk management. } \\
\text { Experience also shows (e.g., in Mali and } \\
\text { Senegal) that success in implementing } \\
\text { IT systems can only be achieved if the following } \\
\text { prerequisites are met: } \\
\text { - IT systems must be introduced as part of a } \\
\text { comprehensive strategy to modernize the tax } \\
\text { administration's structures and procedures. } \\
\text { - Users must embrace the new IT systems and } \\
\text { make the most of them. }\end{array}$ \\
\hline $\begin{array}{l}\text { 5. Developing } \\
\text { human resources }\end{array}$ & $\begin{array}{l}\text { France's support in staff training and } \\
\text { development has been especially } \\
\text { important in most of the } \\
19 \text { Francophone tax administrations. } \\
\text { Additional efforts in this area have } \\
\text { also been provided during workshops } \\
\text { organized by the CREDAF and, more } \\
\text { recently, the AFRITACs. }\end{array}$ & $\begin{array}{l}\text { To improve human resource management in } \\
\text { the } 19 \text { tax administrations, a number of areas } \\
\text { will need to be taken into account, including } \\
\text { the following: } \\
\text { - Major efforts in the areas of staff training } \\
\text { and development, and career planning, will } \\
\text { have to continue to support a successful } \\
\text { implementation of the necessary reforms. } \\
\text { - In spite of some anticorruption initiatives, } \\
\text { the risks in this area are not well controlled, } \\
\text { particularly in countries that have difficulty } \\
\text { adopting pay and incentive systems tailored } \\
\text { to the needs of a modern, professional tax } \\
\text { administration. }\end{array}$ & \\
\hline
\end{tabular}




\begin{tabular}{|c|c|c|c|}
\hline & Main areas of success & Areas where further progress is needed & $\begin{array}{c}\text { Serious shortcomings that require } \\
\text { priority attention }\end{array}$ \\
\hline & & $\begin{array}{l}\text { - Current system in which bonuses are } \\
\text { determined on the basis of penalties } \\
\text { collected by auditors has perverse effects, } \\
\text { and should be replaced with a transparent } \\
\text { system to encourage strong performance by } \\
\text { all staff members. }\end{array}$ & \\
\hline $\begin{array}{l}\text { 6. Strengthening } \\
\text { management and } \\
\text { supervision of the } \\
\text { operational offices }\end{array}$ & & $\begin{array}{l}\text { The information available for evaluating } \\
\text { performance is primarily focused on revenues. } \\
\text { Following the examples of Senegal and Côte } \\
\text { d'Ivoire, initiatives are needed to develop an } \\
\text { approach based on strategic management, } \\
\text { covering the following aspects: } \\
\text { - Identifying a small number of high-priority } \\
\text { goals in the key areas of tax administration. } \\
\text { - Preparing detailed action plans to achieve } \\
\text { these goals. } \\
\text { - Defining criteria for evaluating field } \\
\text { offices' performance in implementing the } \\
\text { action plans. } \\
\text { - Establishing a performance monitoring } \\
\text { mechanism for each criterion defined. } \\
\text { After an adequate period (e.g., } 2 \text { years) to } \\
\text { refine the methods, consideration should be } \\
\text { given to the preparation of performance } \\
\text { contracts. While the tax administration } \\
\text { commits itself to achieving its goals, the } \\
\text { contract must outline the government's } \\
\text { commitment to provide the necessary } \\
\text { resources for modernization and sufficient } \\
\text { flexibility to manage these resources. }\end{array}$ & \\
\hline
\end{tabular}




\begin{tabular}{|c|c|c|c|}
\hline & Main areas of success & Areas where further progress is needed & $\begin{array}{c}\text { Serious shortcomings that require } \\
\text { priority attention }\end{array}$ \\
\hline & & $\begin{array}{l}\text { Experience, however, shows that this is a } \\
\text { difficult undertaking in Africa. Critical efforts } \\
\text { must be made in two areas in particular: } \\
\text { - Implementing the IT tools needed to enable } \\
\text { the tax offices to produce reliable data. } \\
\text { - Guaranteeing that the government will } \\
\text { indeed fulfill its commitments so that the } \\
\text { performance contract will be credible. }\end{array}$ & \\
\hline $\begin{array}{l}\text { 7. Change } \\
\text { management and } \\
\text { coordination of } \\
\text { technical } \\
\text { assistance }\end{array}$ & $\begin{array}{l}\text { The level of resources provided by } \\
\text { the IMF, the World Bank, the } \\
\text { European Union, France, and other } \\
\text { development partners (see Chapter I, } \\
\text { Table 3) shows their dedication to } \\
\text { support the reforms needed in the tax } \\
\text { administrations of the } \\
19 \text { Francophone countries. }\end{array}$ & $\begin{array}{l}\text { Recent creation of change management } \\
\text { structures in some of the } 19 \text { countries' tax } \\
\text { administrations (particularly Senegal) is an } \\
\text { encouraging initiative which should facilitate } \\
\text { a more disciplined and effective approach in } \\
\text { implementing the tax administration reforms. }\end{array}$ & $\begin{array}{l}\text { Experience shows that the efforts necessary to } \\
\text { assure the success of a tax administration's } \\
\text { modernization strategy must be supported by } \\
\text { substantial financial investments and effective } \\
\text { coordination by the development agencies. } \\
\text { In spite of the number of agencies involved and } \\
\text { the extent of the resources provided in a number } \\
\text { of countries (as in Senegal, the DRC, and more } \\
\text { recently Burundi; see Chapter I, Table 3), } \\
\text { progress is still needed in most of the } \\
\text { Francophone countries to develop consistent } \\
\text { modernization projects for the tax } \\
\text { administrations, covering all key aspects } \\
\text { (including, strategy design, reorganization of } \\
\text { structures, reforms of procedures, installation of } \\
\text { IT systems, and development of human } \\
\text { resources), while strengthening project } \\
\text { management and governance. }\end{array}$ \\
\hline
\end{tabular}

